\title{
Life Cycle Sustainability Performance Assessment Method for Comparison of Civil Engineering Works Design Concepts: Case Study of a Bridge
}

\author{
Kristine Ek ${ }^{1,2, *}$, Alexandre Mathern ${ }^{1,2} \oplus$, Rasmus Rempling ${ }^{1,2}\left(\right.$, Petra Brinkhoff ${ }^{1}$, \\ Mats Karlsson ${ }^{2,3}$ and Malin Norin ${ }^{1}$ \\ 1 NCC AB, Gullbergs Strandgata 2, 40514 Göteborg, Sweden; alexandre.mathern@chalmers.se (A.M.); \\ rasmus.rempling@chalmers.se (R.R.); petra.brinkhoff@ncc.se (P.B.); malin.norin@ncc.se (M.N.) \\ 2 Department of Architecture and Civil Engineering, Chalmers University of Technology, 6, 41296 Göteborg, \\ Sweden; mats.d.karlsson@trafikverket.se \\ 3 Swedish Transport Administration, Bataljonsgatan 8, 55305 Jönköping, Sweden \\ * Correspondence: kristine.ek@ncc.se
}

Received: 9 October 2020; Accepted: 23 October 2020; Published: 28 October 2020

check for updates

\begin{abstract}
Standardized and transparent life cycle sustainability performance assessment methods are essential for improving the sustainability of civil engineering works. The purpose of this paper is to demonstrate the potential of using a life cycle sustainability assessment method in a road bridge case study. The method is in line with requirements of relevant standards, uses life cycle assessment, life cycle costs and incomes, and environmental externalities, and applies normalization and weighting of indicators. The case study involves a short-span bridge in a design-build infrastructure project, which was selected for its generality. Two bridge design concepts are assessed and compared: a concrete slab frame bridge and a soil-steel composite bridge. Data available in the contractor's tender phase are used. The two primary aims of this study are (1) to analyse the practical application potential of the method in carrying out transparent sustainability assessments of design concepts in the early planning and design stages, and (2) to examine the results obtained in the case study to identify indicators in different life cycle stages and elements of the civil engineering works project with the largest impacts on sustainability. The results show that the method facilitates comparisons of the life cycle sustainability performance of design concepts at the indicator and construction element levels, enabling better-informed and more impartial design decisions to be made.
\end{abstract}

Keywords: sustainability; life cycle assessment; life cycle costing; environmental externalities; indicator; multi-criteria decision analysis; civil engineering; bridge; design

\section{Introduction}

In civil engineering projects, life cycle environmental, social, and economic sustainability performance is becoming increasingly important, as reflected in the large number of standards published on the subject in recent years [1-4]. To make better-informed decisions regarding the impact of design choices on the sustainability of civil engineering works, sustainability performance assessment is recommended [5,6]. It is important that assessments are performed in a harmonized way and can be compared impartially. Current standards provide the general framework for the sustainability assessment of civil engineering works but do not give detailed guidance on the calculation of indicators and their aggregation [2,4]. In most studies on sustainability-based design and optimization of bridges, simplifications are used, and the assessment is based on one or two selected indicators and only covers certain life cycle stages [6], e.g., $\mathrm{CO}_{2}$ emissions and the cost of construction materials [7] and of transport and installation [8] and embodied energy of construction materials [9]. 
The potential to influence the sustainability of a design is larger in the early stages of the design process than in later stages [10]. It is therefore important to define indicators that can support an iterative sustainability-driven design process from concept to final implementation. To enable the identification of sustainable designs, a formalized method that allows transparent, comparable, and automatable sustainability design and assessment is desired.

Ek et al. presented a harmonized method for life cycle sustainability assessment and comparison of civil engineering works design concepts [11]. The proposed method includes guidance on the calculation of environmental, social and economic indicators, based on life cycle assessment (LCA), life cycle costing (LCC) and external costs, and aggregation using normalization and weighting factors, in accordance with the principles and requirements of methods for sustainability performance assessment given in the standards [2] and [4].

This paper evaluates the previously proposed method by applying it in a road bridge case study. The study has two primary aims: (1) to analyse the practical application potential of the method in carrying out transparent sustainability assessments of design concepts in the early planning and design stages and (2) to examine the results obtained in the case study to identify critical indicators in different life cycle stages as well as critical elements in the civil engineering works project with the greatest impacts.

Life cycle stages are classified into so-called modules by the related standards $[1-4,12-15]$, see Figure 1.

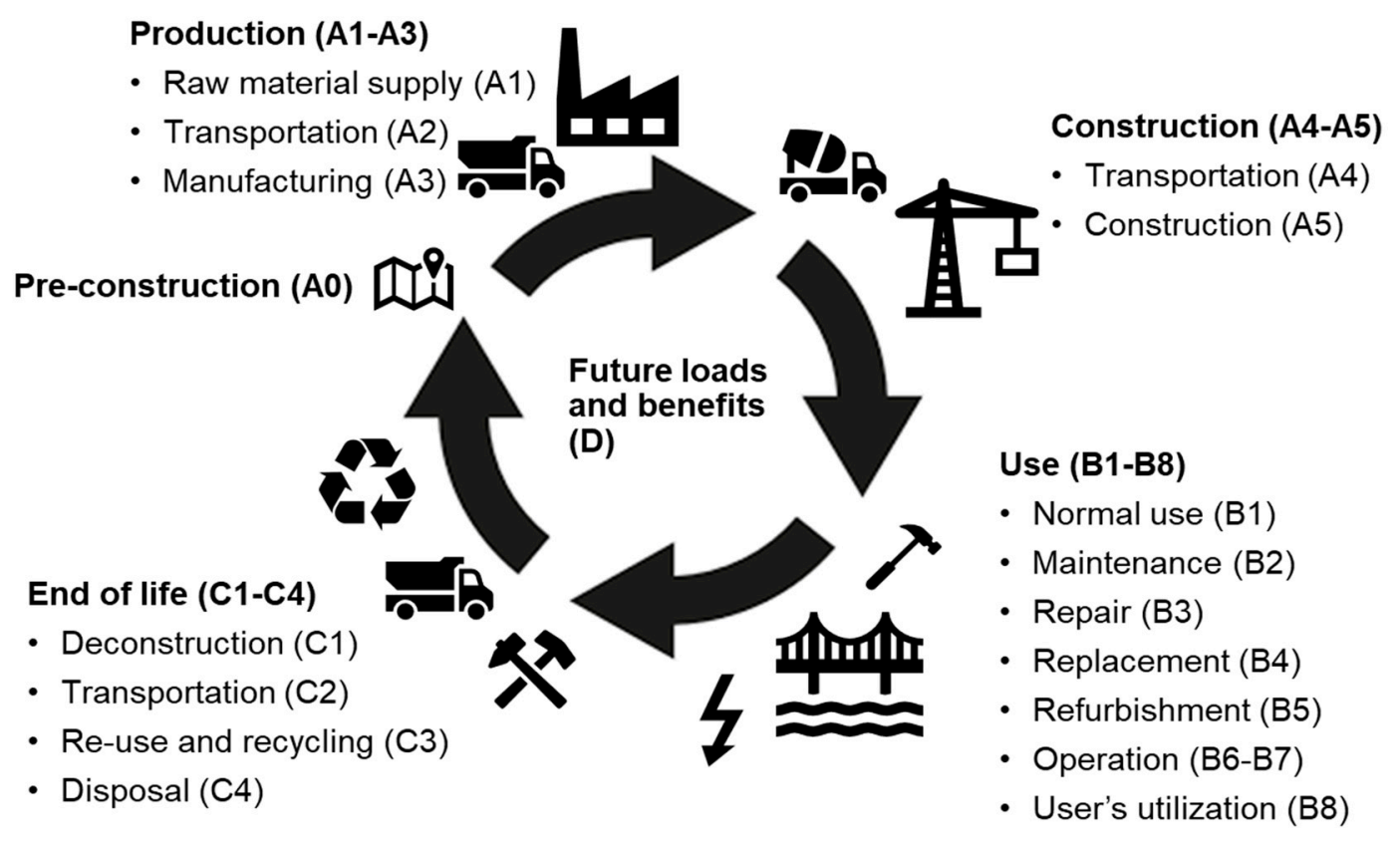

Figure 1. Schematic illustration of the life-cycle stages of a civil engineering works project and their classification in modules.

Module A0 is the pre-construction stage. Modules A1-A3 represent the production stage from raw material extraction to construction material manufacturing where A1 is material extraction, $\mathrm{A} 2$ is transport from extraction to manufacture, and A3 is material manufacture. A4-A5 represent the construction process stage where $\mathrm{A} 4$ is transport from material manufacture to the construction site and A5 is the construction site works. B1-B5 represent the use stage relating to maintenance where B1 is normal use of the bridge, B2 is maintenance, B3 is repair, B4 is replacement, and B5 is refurbishment. B6-B7 represent the use stage related to the operation where B6 is operational energy use and B7 is operational water use. B8 is the use stage related to the user's utilization of the civil engineering works. $\mathrm{C} 1-\mathrm{C} 4$ cover the end-of-life stage where $\mathrm{C} 1$ is deconstruction, $\mathrm{C} 2$ is transport from the deconstruction site to the waste management site, $\mathrm{C} 3$ is the waste processing of materials intended for reuse, recycling, 
and energy recovery, and C4 is waste disposal. Module D represents the benefits and loads beyond the system boundary of the civil engineering works.

\section{Materials and Methods}

The new method for life cycle sustainability assessment and comparison of civil engineering works design concepts presented by Ek et al. [11] was applied to a case study. The case study involved a bridge in a design-build infrastructure project and was selected for its generality. Two alternative bridge design concepts were assessed and compared: a concrete slab frame bridge (CSF bridge) and a soil-steel composite bridge (SSC bridge). The prerequisites for the assessment are presented in Table 1.

Table 1. Case study specific prerequisites for the assessment.

\begin{tabular}{|c|c|}
\hline Characteristic & Case Study Prerequisite \\
\hline Object of assessment & $\begin{array}{l}\text { Bridge 6-1282-1 on Road 26, Sweden } \\
6 \mathrm{~m} \text { long, } 9 \mathrm{~m} \text { wide, } 3 \text { road lanes }\end{array}$ \\
\hline Intended use of the assessment & Design concept comparison \\
\hline Additional functions provided & - \\
\hline $\begin{array}{l}\text { Functional equivalent: } \\
\text { (a) Type/use of the civil engineering works, } \\
\text { (b) Capacity, } \\
\text { (c) Reference study period and pattern of use, } \\
\text { (d) Design life (required service life, RSL) }\end{array}$ & $\begin{array}{l}\text { (a) Road bridge with fauna passage } \\
\text { (b) } 7200 \text { AADT, } 100 \mathrm{~km} / \mathrm{h} \\
\text { (c) } 80 \text { years, see Appendices C and D } \\
\text { (d) } 80 \text { years }\end{array}$ \\
\hline Time of assessment in the life cycle & Detailed design/tender phase \\
\hline Life cycle stages assessed & A1-A5, B1-B8, C1-C4, D \\
\hline Justification of the exclusion of modules & $\begin{array}{l}\text { A0 was excluded because of its insignificant impact } \\
\text { on the sustainability performance and because it does } \\
\text { not differ between the concepts. }\end{array}$ \\
\hline Area of influence & $\begin{array}{l}\text { Environmental, social, and economic dimensions } \\
\text { (environmental externalities): The surroundings and } \\
\text { people in the direct vicinity of the bridge, receiving } \\
\text { emissions from fuel combustion and other activities } \\
\text { during construction, use and deconstruction from } \\
\text { passing vehicles across the length of the bridge. } \\
\text { Economic dimension (Life cycle costs (LCC) and } \\
\text { incomes): The users of passing vehicles on the bridge } \\
\text { (module B8), the client of the constructed bridge (all } \\
\text { other modules). }\end{array}$ \\
\hline Energy and mass flows considered in the assessment & See Appendices B-D \\
\hline General assumptions and scenarios used & See Appendices B-D \\
\hline Sources of data for the indicators & See Appendices B-D \\
\hline Statement about whether data are specific or generic & See Appendix A \\
\hline Reference year for the cost data & 2019 \\
\hline
\end{tabular}

The functional unit is $1 \mathrm{~m}$ of bridge length and year of required service life (RSL). The reference study period is equal to the required service life: 80 years. A functional equivalent of $1 \mathrm{~km}$ of bridge and year of RSL is prescribed by the product category rules (PCR) of the International EPD System [13], but it was decided to use $1 \mathrm{~m}$ instead, because the short length of the bridge $(6 \mathrm{~m})$ would yield non-representative results if scaled to $1 \mathrm{~km}$.

Life cycle assessment (LCA) was performed according to the standard EN 15804 [12] using the LCA software GaBi Professional, version 9.5 (Sphera Solutions GmbH, Leinfelden-Echterdingen, Germany) [16]. The GaBi datasets used are presented in Appendix A. Normalization and weighting 
factors presented in [11] (adapted from the factors used in the Product Environmental Footprint (PEF) method [17-19] were used (see Table 2). As proposed in [11], some indicators are categorized into the environmental dimension and some into the social dimension. In PEF, all indicators are in a single dimension. The PEF weighting factors of the indicators have thus been scaled to a total of 100 in the environmental and social dimension, respectively. The life cycle costing (LCC and incomes) was calculated according to the standard EN 15686-5 [14], and environmental externalities were calculated in accordance with ISO 14008 [15]. The economic indicators are presented separately in line with the standards' requirements. LCC and incomes as well as environmental externalities are presented as the net present value (NPV) using a discount rate of 3\%. This discount rate was chosen as it is the rate prescribed by the currently available standard on calculation methods for economic performance (for buildings) [20]. Environmental externalities were calculated using the EPS 2015dx method [21]. Abbreviations and units of measurement used for the indicators included in the assessment are presented in Table 3.

Table 2. Normalization and weighting factors used for environmental and social indicators [11].

\begin{tabular}{|c|c|c|c|}
\hline Dimension & Indicator & $\begin{array}{l}\text { Normalization } \\
\text { Factor (NF) }\end{array}$ & $\begin{array}{l}\text { Weighting } \\
\text { Factor (\%) }\end{array}$ \\
\hline \multirow{11}{*}{ Environmental } & Acidification potential & 55.6 & 8.43 \\
\hline & Eco-toxicity potential (freshwater) & 42,683 & 2.61 \\
\hline & Potential soil quality index & 819,498 & 10.80 \\
\hline & Global warming potential total (fossil + biogenic + luluc) & 8096 & 28.63 \\
\hline & Abiotic depletion potential for non-fossil resources & 0.0636 & 10.27 \\
\hline & Abiotic depletion potential for fossil resources & 65,004 & 11.31 \\
\hline & Eutrophication potential (freshwater) & 1.61 & 3.81 \\
\hline & Eutrophication potential (marine) & 19.5 & 4.02 \\
\hline & Eutrophication potential (terrestrial) & 177 & 5.04 \\
\hline & Ozone depletion potential & 0.0536 & 8.58 \\
\hline & Photochemical ozone creation potential & 40.6 & 6.50 \\
\hline \multirow{5}{*}{ Social } & Potential ionizing radiation-human health & 4220 & 18.94 \\
\hline & Human toxicity potential-cancer effects & 0.0000169 & 8.05 \\
\hline & Human toxicity potential-non-cancer effects & 0.000230 & 6.96 \\
\hline & Particulate matter emissions & 0.000595 & 33.88 \\
\hline & Water user deprivation potential & 11,469 & 32.17 \\
\hline
\end{tabular}

The method requires the use of a life cycle inventory (LCI) to calculate the indicators. In the case study, the LCI was in the form of a bill of materials (BOM), which was calculated for each design concept for modules A1-A5 as well as for the use (B1-B8) and end-of-life (C1-C4 and D) stages. It was created based on data available in the tender phase. The BOM is presented in Appendix B. The values of modules B1-B8, C1-C4, and D were calculated based on the scenarios presented in Appendix C. Realistic and representative scenarios of the resource consumption and costs of modules B-D were developed for each design concept. Scenarios were developed based on project documentation and literature data, if available, as well as expert knowledge. Expert knowledge was based on both the project manager of the construction project used as case study, and the authors' previous experience from bridge design, construction and maintenance projects in Sweden.

For the LCC, the average market prices per unit for each of the resources included were used. Average prices were supplied by the project manager of the case study project.

Transport modes and distances are presented in Appendix D. Cut-offs were made for the transport of form oil, bitumen sheet, bitumen sealant, impregnation, geotextile, mortar, graffiti protection, polypropylene pipe, polyethylene foam, bituprimer, epoxy sealant, and plastic film. 
Table 3. Sustainability dimensions, categories, indicator names, abbreviations, and units of measurement for the indicators.

\begin{tabular}{|c|c|c|c|c|}
\hline Dimension & Category & Indicator Name & Abbreviation & Unit of Measurement \\
\hline \multirow{11}{*}{ Environmental } & Acidification & Acidification potential & $\mathrm{AP}$ & $\mathrm{mol} \mathrm{H}+\mathrm{eq}$ \\
\hline & \multirow{2}{*}{ Biodiversity } & Eco-toxicity potential (freshwater) & ETP-fw & CTUe \\
\hline & & Potential soil quality index & SQP & Dimensionless \\
\hline & Climate change & $\begin{array}{l}\text { Global warming potential total } \\
\text { (fossil + biogenic + luluc) }\end{array}$ & GWP-total & $\mathrm{kg} \mathrm{CO}_{2}$ eq \\
\hline & $\begin{array}{l}\text { Depletion of abiotic } \\
\text { resources-minerals } \\
\text { and metals }\end{array}$ & $\begin{array}{l}\text { Abiotic depletion potential } \\
\text { for non-fossil resources }\end{array}$ & ADPE & $\mathrm{kg} \mathrm{Sb} \mathrm{eq}$ \\
\hline & $\begin{array}{l}\text { Depletion of abiotic } \\
\text { resources-fossil fuels }\end{array}$ & $\begin{array}{l}\text { Abiotic depletion potential } \\
\text { for fossil resources }\end{array}$ & $\mathrm{ADPF}$ & MJ, net calorific value \\
\hline & \multirow{3}{*}{ Eutrophication } & Eutrophication potential (freshwater) & EP-freshwater & $\mathrm{kg} P$ eq \\
\hline & & Eutrophication potential (marine) & EP-marine & $\mathrm{kg} \mathrm{N} \mathrm{eq}$ \\
\hline & & Eutrophication potential (terrestrial) & EP-terrestrial & mol N eq \\
\hline & Ozone depletion & Ozone depletion potential & ODP & $\mathrm{kg} \mathrm{CFC} 11 \mathrm{eq}$ \\
\hline & $\begin{array}{l}\text { Photochemical } \\
\text { ozone creation }\end{array}$ & Photochemical ozone creation potential & POCP & kg NMVOC eq \\
\hline \multirow{5}{*}{ Social } & \multirow{5}{*}{ Health and comfort } & $\begin{array}{l}\text { Potential ionizing } \\
\text { radiation-human health }\end{array}$ & PIR & kBq U235 eq \\
\hline & & $\begin{array}{c}\text { Human toxicity } \\
\text { potential—cancer effects }\end{array}$ & HTP c & CTUh \\
\hline & & $\begin{array}{c}\text { Human toxicity } \\
\text { potential—non-cancer effects }\end{array}$ & HTP nc & CTUh \\
\hline & & Particulate matter emissions & PM & Disease incidence \\
\hline & & Water user deprivation potential & WDP & $\mathrm{m}^{3}$ world deprived eq \\
\hline \multirow{2}{*}{ Economic } & $\begin{array}{c}\text { Life cycle } \\
\text { economic balance }\end{array}$ & LCC and incomes & - & Euro \\
\hline & External cost & Environmental externalities & - & Euro \\
\hline
\end{tabular}

\section{Results}

The results are first presented separately for the CSF bridge design concept and the SSC bridge design concept. The results for the two concepts are then compared. Positive economic indicator values indicate costs, while negative values indicate incomes. For the environmental and social indicators, positive values indicate a negative impact, and negative values indicate a positive impact.

The result for module B8 is presented in a separate figure, since it is relatively higher than that of the other modules. Furthermore, the result for module B8 was excluded from the comparison of the concepts, since it would have disguised the differences in concepts among the other modules. In addition, the result for module B8 was found to be equal for both concepts.

\subsection{Concrete Slab Frame Bridge Design Concept}

The results for each indicator of the sustainability assessment of the CSF bridge in units of measurement and per life cycle stage are presented in Table 4.

The results for the CSF bridge are presented per life cycle stage in Table 5. The results for the environmental and social dimensions are aggregated on the dimension level, using the normalization and weighting factors in Table 2, while the results for the economic dimension are summarized at the indicator level. The normalized and weighted results for the environmental and social dimensions are presented per life cycle stage and per indicator in Figure 2 (excluding module B8). Figure 3 shows the contribution of each resource to the total impact over the life cycle (modules A-C excluding B8) in the environmental dimension and the social dimension, respectively, for the resources with the greatest contributions. The normalized and weighted results for the environmental and social dimensions are presented for module B8 per indicator in Figure 4. 
Table 4. Results for the concrete slab frame bridge (CSF) bridge design concept per indicator in units of measurement per life-cycle stage for the functional unit. Modules not assessed are abbreviated as "MNA".

\begin{tabular}{ccccccccc}
\hline Indicator & A0 & A1-A3 & A4-A5 & B1-B5 & B6-B7 & B8 & C1-C4 & D \\
\hline AP & MNA & 0.78 & 0.57 & 0.049 & 0 & 4.2 & 0.29 & -0.18 \\
ETP-fw & MNA & 1780 & 1642 & 133 & 0 & 4063 & 380 & -333 \\
SQP & MNA & 1002 & 7588 & 22 & 0 & 22,083 & 167 & -579 \\
GWP-total & MNA & 313 & 172 & 12 & 0 & 234 & 47 & -70 \\
ADPE & MNA & $2.1 \times 10^{-4}$ & $1.6 \times 10^{-5}$ & $4.4 \times 10^{-6}$ & 0 & $5.4 \times 10^{-5}$ & $3.7 \times 10^{-6}$ & $-1.0 \times 10^{-4}$ \\
ADPF & MNA & 3740 & 2344 & 230 & 0 & 5229 & 584 & -892 \\
EP-freshwater & MNA & $5.5 \times 10^{-4}$ & $5.6 \times 10^{-4}$ & $2.6 \times 10^{-5}$ & 0 & $3.110^{-2}$ & $1.1 \times 10^{-4}$ & $-2.3 \times 10^{-4}$ \\
EP-marine & MNA & 0.24 & 0.25 & 0.015 & 0 & 1.68 & 0.10 & -0.05 \\
EP-terrestrial & MNA & 2.61 & 2.82 & 0.17 & 0 & 20.4 & 1.1 & -0.5 \\
ODP & MNA & $6.9 \times 10^{-11}$ & $2.6 \times 10^{-11}$ & $3.1 \times 10^{-11}$ & 0 & $4.9 \times 10^{-10}$ & $8.5 \times 10^{-14}$ & $-3.5 \times 10^{-13}$ \\
POCP & MNA & 0.64 & 0.71 & 0.046 & 0 & 2.7 & 0.28 & -0.14 \\
PIR & MNA & 60 & 3.1 & 0.57 & 0 & 148.5 & 0.39 & -13 \\
HTP c & MNA & $1.8 \times 10^{-6}$ & $5.6 \times 10^{-8}$ & $1.2 \times 10^{-8}$ & 0 & $7.1 \times 10^{-7}$ & $2.9 \times 10^{-8}$ & $-5.8 \times 10^{-8}$ \\
HTP nc & MNA & $4.8 \times 10^{-6}$ & $2.0 \times 10^{-6}$ & $4.3 \times 10^{-7}$ & 0 & $1.1 \times 10^{-4}$ & $2.9 \times 10^{-6}$ & $-6.9 \times 10^{-7}$ \\
PM & MNA & $1.5 \times 10^{-5}$ & $1.2 \times 10^{-5}$ & $5.8 \times 10^{-7}$ & 0 & $4.1 \times 10^{-5}$ & $2.4 \times 10^{-6}$ & $-3.2 \times 10^{-6}$ \\
WDP & MNA & 71 & 11 & 0.86 & 0 & 109 & 6.3 & -16 \\
LCC and incomes & MNA & 210 & 287 & 18 & 0 & 86 & 12 & -1.1 \\
Environmental externalities & MNA & 123 & 56 & 2.0 & 0 & 31 & 1.4 & -7.8 \\
\hline
\end{tabular}

Table 5. Results for the CSF bridge design concept per life cycle stage aggregated on the dimension level (and on the indicator level for the economic dimension) for the functional unit. The results for the environmental and social dimensions are normalized and weighted, and the results for the economic dimension are summarized. Modules not assessed are abbreviated as "MNA".

\begin{tabular}{ccccccccc}
\hline Dimension & Indicator (Unit) & A0 & A1-A3 & A4-A5 & B1-B7 & B8 & C1-C4 & D \\
\hline Environmental & All (dimensionless) & MNA & 2.3 & 1.6 & 0.12 & 4.4 & 0.43 & -1.5 \\
Social & All (dimensionless) & MNA & 2.3 & 0.82 & 0.057 & 6.9 & 0.26 & -1.2 \\
Economic & LCC and incomes (Euro) & MNA & 210 & 287 & 18 & 86 & 12 & -1.1 \\
& Environmental externalities (Euro) & MNA & 123 & 56 & 2.0 & 31 & 1.4 & -7.8 \\
\hline
\end{tabular}

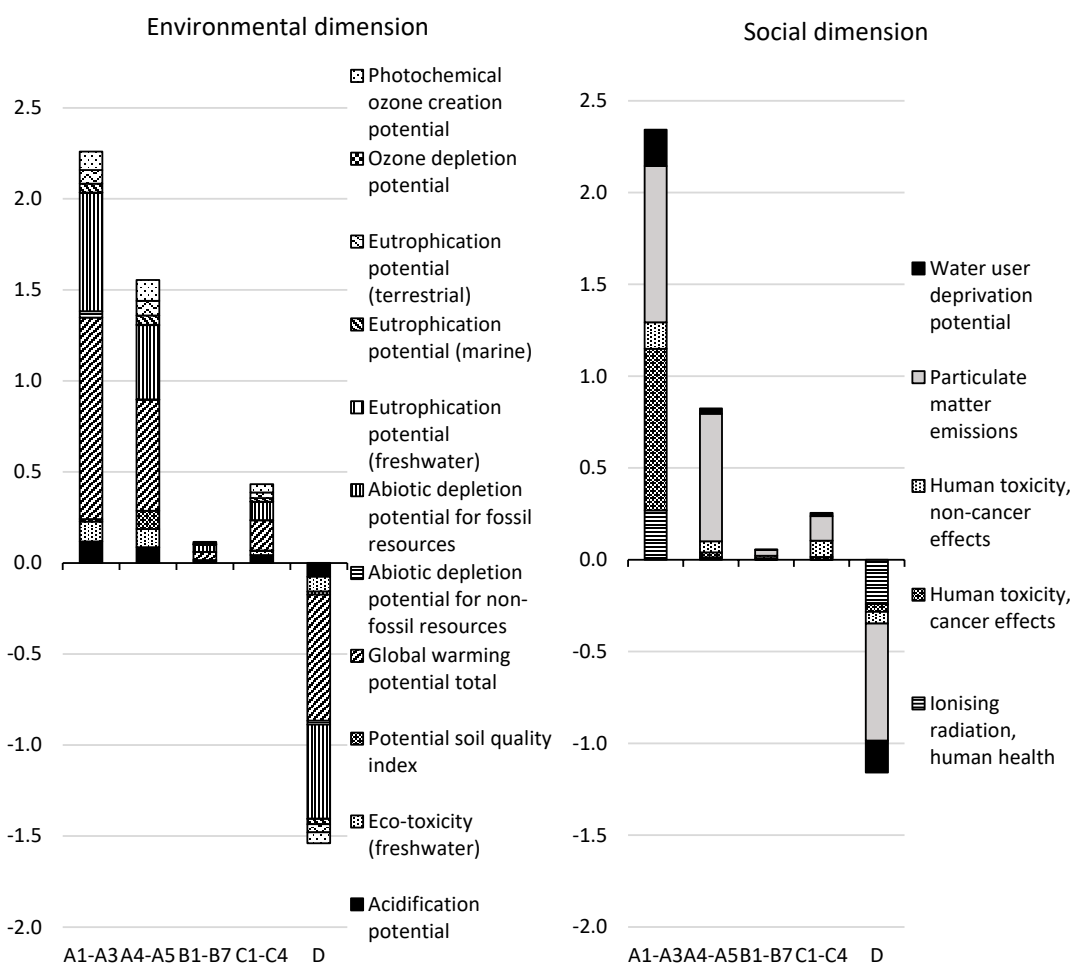

(a)

(b)

Figure 2. Normalized and weighted results for the CSF bridge design concept per life cycle stage in (a) the environmental dimension and (b) the social dimension for each indicator and for the functional unit. Module B8 is not included. See Figure 4 for module B8. Note that the ozone depletion potential indicator bar cannot be seen in the figure since it is very small. 
In the environmental dimension, $52 \%$ of the total impact of life cycle stages $\mathrm{A}-\mathrm{C}$, excluding module $\mathrm{B} 8$, occurs in the production stage (modules A1-A3), followed by the construction stage $(36 \%$, modules A4-A5). If included, B8 would contribute to $50 \%$ of the total impact for life cycle stages A-C. Module $\mathrm{D}$ presents the potential to reduce the environmental impact of life cycle stages A-C (excluding module B8) by $35 \%$ through future re-use or recycling. The main contribution to the environmental impact over the life cycle (modules A-C, excluding B8) comes from the indicators "global warming potential" ( $44 \%$ of the total impact) and "abiotic depletion potential for fossil resources" ( $28 \%$ of the total impact, see Figure 2). Fifty-one percent of the global warming potential is caused by the production $(29 \%)$ and transport to the construction site $(22 \%)$ of 6833 tons of aggregates, while $23 \%$ is caused by the production of 472 tons of concrete, and $6 \%$ is caused by the production and combustion of diesel used on the site during construction. The production and transport of aggregates and the landfilling of aggregate waste contributes to $53 \%$ of the total environmental impact over the life cycle (see Figure 3 ).

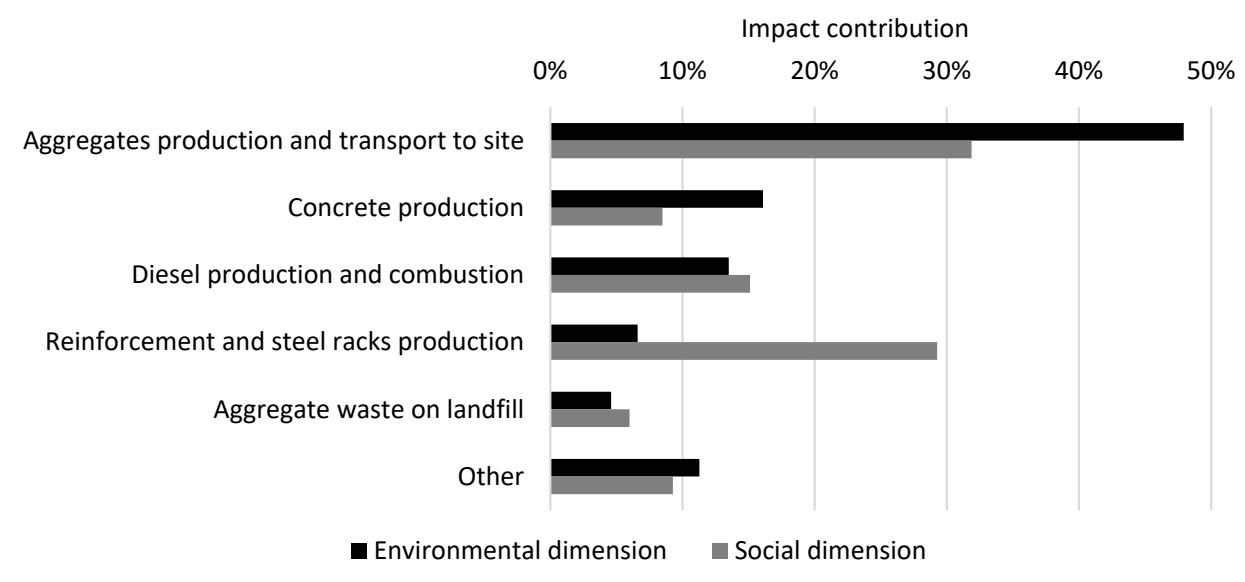

Figure 3. Contribution of resources to the total impact over the life cycle (modules A-C, excluding B8) for the CSF bridge design concept in the environmental and social dimensions.

In the social dimension, $67 \%$ of the total impact for life cycle stages A-C (excluding module B8) occurs in the production stage, followed by the construction stage (24\%). If included, module B8 would contribute to $66 \%$ of the total impact for life cycle stages A-C. Module D presents the potential to reduce the social impact by $33 \%$ of the total impact for life cycle stages A-C (excluding module B8) by future re-use or recycling. The main contribution to social impact over the life cycle (modules A-C, excluding B8) comes from the indicators "particulate matter emissions" (49\% of the total impact) and "human toxicity-cancer effects" ( $27 \%$ of the total impact). Thirty-five percent of the particulate matter emissions are caused by the production of aggregates and their transport to the construction site, and $28 \%$ is caused by the production and combustion of diesel at the construction site during construction. The production and transport of aggregates and the landfilling of aggregate waste contributes to $38 \%$ and reinforcement steel and steel rack production contributes to $29 \%$ of the total social impact over the life cycle (see Figure 3).

In the economic dimension, $54 \%$ of the total net cost for the indicator "LCC and incomes" in life cycle stages A-C (excluding module B8) occurs in the construction stage (mainly in A5), see Table 5. Forty percent occurs in the production stage. If module B8 was included, it would contribute to $14 \%$ of the total net cost for life cycle stages A-C. Module D presents the potential to reduce the future net cost (by future re-use or recycling) by $0.2 \%$ for life cycle stages $\mathrm{A}-\mathrm{C}$ (excluding module B8). The main contributor $(30 \%)$ to the cost of the LCC and incomes over the life cycle is the work costs during construction, followed by the costs for production and transport of aggregates (18\%) and for the production and transport of concrete and reinforcement steel $(17 \%)$. For the indicator "environmental externalities", $68 \%$ of the total cost in life cycle stages A-C (excluding module B8) occurs in the production stage, followed by the construction stage (31\%). If module B8 was included, 
it would contribute to $12 \%$ of the total cost for life cycle stages A-C. Module D presents the potential to reduce future costs of the total impact for life cycle stages A-C (excluding module B8) by $4 \%$. The main contributors ( $43 \%$ ) to the environmental externalities over the life cycle are the production and transport of aggregates and transport to waste disposal and the landfilling of aggregate waste.

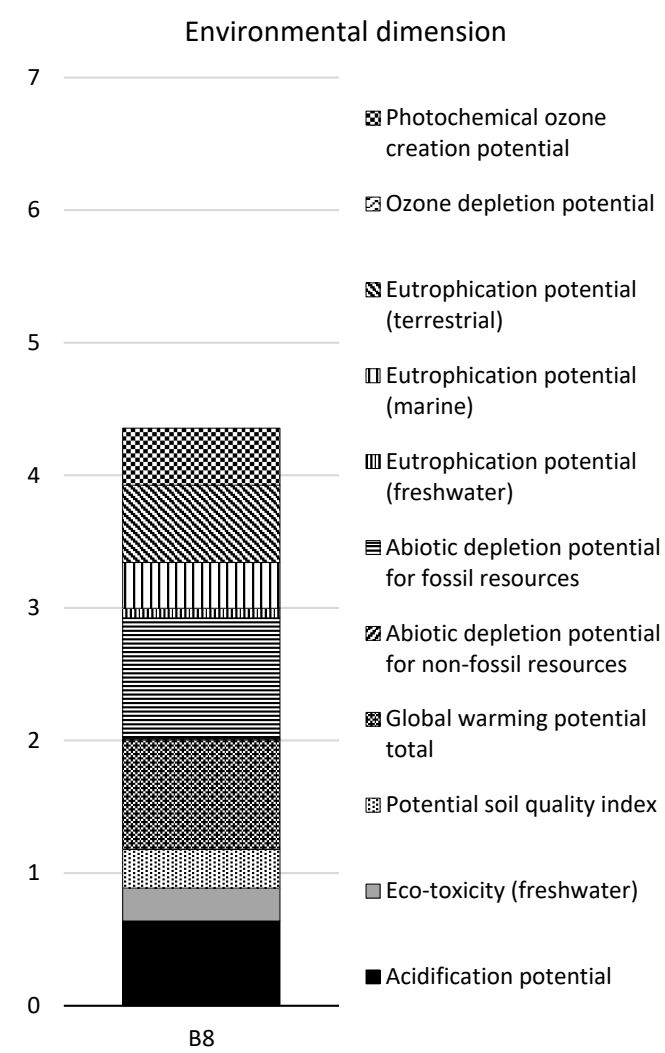

(a)

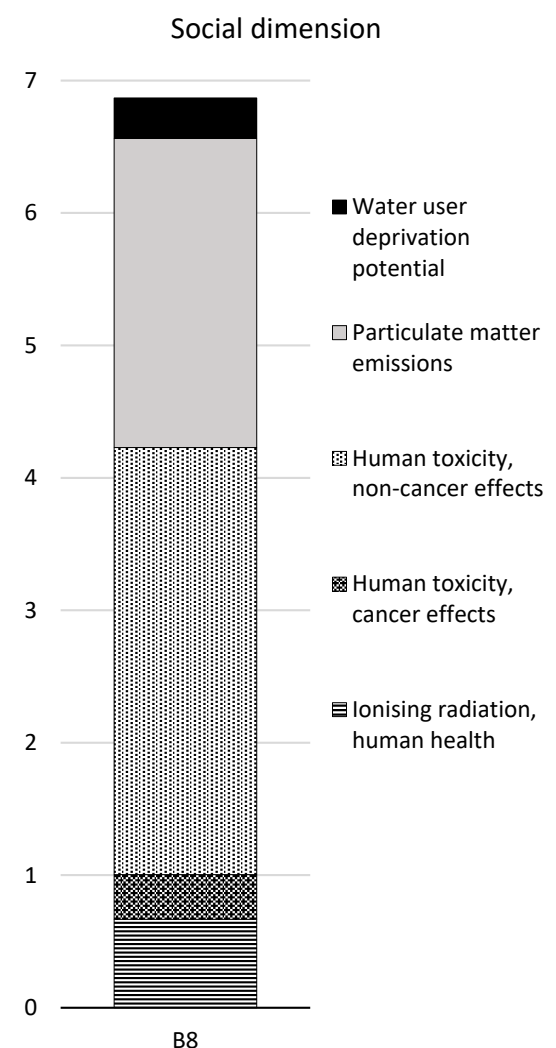

(b)

Figure 4. Normalized and weighted results for module B8 for both bridge design concepts in (a) the environmental dimension and (b) the social dimension for each indicator and for the functional unit. Note that the ozone depletion potential indicator bar cannot be seen in the figure since it is very small.

\subsubsection{Modules A1-A3}

In the production stage, greenhouse gas emissions have the largest impact in the environmental dimension (see Figure 2). The indicator "global warming potential" contributes to $49 \%$ of the total impact in this life cycle stage. Fifty percent of this originates from the production of 6833 tons of aggregates, 39\% from the production of 472 tons of concrete, and 9\% from the production of 23 tons of reinforcement steel (carbon and stainless). The production of asphalt, steel racks, and other built-in construction materials accounts for $2 \%$ of the global warming potential.

The second largest impact comes from the abiotic depletion potential for fossil resources; this constitutes $29 \%$ of the total environmental impact. Sixty-eight percent of this depletion is caused by the production of aggregates, $16 \%$ by the production of concrete, and $11 \%$ by the production of reinforcement steel.

The "acidification potential", the "eco-toxicity potential", and the "photochemical ozone creation potential" indicators also have significant impacts, each accounting for about $5 \%$ of the total environmental impact. The production of aggregates contributes to $46-69 \%$ of the total impact for each of these indicators. 
The largest impact in the social dimension comes from the indicators "human toxicity-cancer effects" (38\%) and "particulate matter emissions" (36\%). For "human toxicity-cancer effects", $97 \%$ of the impact comes from the production of $553 \mathrm{~kg}$ of stainless-steel reinforcement. For "particulate matter emissions", $66 \%$ of the impact comes from the production of aggregates.

In the economic dimension, for the indicator "LCC and incomes", 39\% of the total cost is for the aggregates, $23 \%$ is for the ready-mix concrete, and $19 \%$ is for carbon steel reinforcement. There is no income. For the indicator "environmental externalities", $36 \%$ of the total cost is for the production of aggregates, and $20 \%$ each is for the production of stainless-steel reinforcement and ready-mix concrete.

\subsubsection{Modules A4-A5}

In the construction process stage, greenhouse gas emissions have the largest impact in the environmental dimension (see Figure 2). The global warming potential accounts for $39 \%$ of the total impact in this life cycle stage. Seventy percent of this type of emission originates from the transport of aggregates from the production site to the construction site. Eighteen percent originates from the production and combustion of diesel in construction machines on the construction site.

The second largest impact comes from the abiotic depletion potential for fossil resources, having $26 \%$ of the total environmental impact. Sixty-eight percent of this is caused by the transport of aggregates to the site.

The third largest impact comes from the combination of the three indicators for eutrophication potential, together contributing to $9 \%$ of the total environmental impact. Approximately $72 \%$ of the eutrophication potential (marine) and eutrophication potential (terrestrial) comes from the production and combustion of diesel used on site, while $65 \%$ of the eutrophication potential (freshwater) comes from the transport of aggregates.

Significant impacts are also caused by the "eco-toxicity potential", the "potential soil quality index", and the "photochemical ozone creation potential" indicators, each accounting for 6-7\% of the total environmental impact. The transport of aggregates contributes to $69 \%$ of the eco-toxicity potential. Ninety percent of the potential soil quality index value comes from the production of the ancillary materials wood, particleboard, and plywood for the formworks. The production and combustion of diesel used on the construction site contributes to $74 \%$ of the photochemical ozone formation potential.

The largest impact in the social dimension comes from particulate matter emissions (84\%). Sixty-nine of this is caused by the production and combustion of diesel used on the construction site.

In the economic dimension, for the indicator "LCC and incomes", $65 \%$ of the total cost is for the construction workers and $11 \%$ is for the transport of aggregates. There is no income. For the indicator "environmental externalities", $62 \%$ of the total cost is for the transport of aggregates, and $25 \%$ is for the production and combustion of diesel used on the construction site.

\subsubsection{Modules B1-B7}

In the use stage, "global warming potential" (38\%) has the largest impact in the environmental dimension, followed by "abiotic depletion for fossil resources" (35\%), see Figure 2. Fifty-three percent of the global warming potential is caused by the production of 1.4 tons of steel racks, and $30 \%$ is caused by the production of 14 tons of ready-mix concrete. Thirty-two percent of the abiotic depletion potential for fossil resources is caused by the production of 10.5 tons of asphalt.

"Particulate matter emissions" (58\% of the total impact) has the largest impact in the social dimension, followed the indicator "human toxicity-non-cancer effects" (23\%). Thirty-nine percent of the particulate matter emissions is caused by the production of steel racks, and $21 \%$ is caused by the production of $35 \mathrm{~kg}$ of bituprimer. The largest contributor to "human toxicity-non-cancer effects" is the production of $77 \mathrm{~kg}$ of epoxy (45\%). 
In the economic dimension, for the indicator "LCC and incomes", $46 \%$ of the total cost is for steel racks. The cost for installation of the steel racks is $21 \%$ of the total cost. There is no income. For the indicator "environmental externalities", 61\% of the total cost is for the production of steel racks, and $23 \%$ is for the production of asphalt.

\subsubsection{Module B8}

The impact of module B8, the stage relating to the user's utilization, is the same for both design concepts (see Figure 4, Tables 5 and 6). For the CSF bridge, the environmental impact of module B8 is equal to the environmental impact of all other modules together (excluding module D). The social impact of module B8 is $97 \%$ greater. The net cost for LCC and incomes is $84 \%$ lower for module B8 than for all other modules together (excluding module D). The "environmental externalities" indicator is $83 \%$ lower for module B8 than for all other modules together (excluding module D).

Table 6. Results for the SSC bridge design concept per life cycle stage and aggregated at the dimension level (or at the indicator level for the economic dimension) for the functional unit. The results for the environmental and social dimensions are normalized and weighted, and the results for the economic indicators are summarized. Modules not assessed are abbreviated as "MNA".

\begin{tabular}{ccccccccc}
\hline Dimension & Indicator (Unit) & A0 & A1-A3 & A4-A5 & B1-B7 & B8 & C1-C4 & D \\
\hline Environmental & All (dimensionless) & MNA & 5.0 & 1.4 & 0.078 & 4.4 & 0.44 & -2.1 \\
Social & All (dimensionless) & MNA & 1.6 & 0.63 & 0.029 & 6.9 & 0.25 & -1.4 \\
Economic & LCC and incomes (Euro) & MNA & 295 & 99 & 16 & 86 & 10 & -0.8 \\
& Environmental externalities (Euro) & MNA & 1087 & 52 & 1.5 & 31 & 1.3 & -14 \\
\hline
\end{tabular}

The indicators "abiotic depletion potential for fossil resources" and "global warming potential" account for $21 \%$ and $19 \%$ of the total impact, respectively, in the environmental dimension. Fifteen percent comes from the indicator "acidification potential", and 13\% comes from the indicator "eutrophication potential" (terrestrial). However, if the results for all three eutrophication indicators are pooled, they account for $23 \%$ of the total environmental impact. Fifty-four percent of the global warming potential originates from the production and combustion of hydrogenated vegetable oil (HVO) (rapeseed methyl ester (RME) was used as a proxy for HVO). Fifty-eight percent of the abiotic depletion potential for fossil resources originates from the production of electricity. Seventy-six percent of the total eutrophication potential originates from the production and combustion of HVO.

Forty-seven percent of the total impact in the social dimension comes from the indicator "human toxicity potential-non-cancer effects", and 34\% comes from "particulate matter emissions". Ninety-seven percent of the "human toxicity potential-non-cancer effects" originates from the production of HVO. For particulate matter emissions, $48 \%$ originates from the production of $\mathrm{HVO}$, and $45 \%$ comes from the combustion of diesel.

In the economic dimension, for the indicator "LCC and incomes", $46 \%$ of the total cost is for steel racks. The cost for installation of the steel racks is $21 \%$ of the total cost. There is no income. For the indicator "environmental externalities", the largest contributor is the production of HVO.

\subsubsection{Modules C1-C4}

In the end-of-life stage, global warming potential has the largest impact in the environmental dimension (38\%), followed by abiotic depletion potential for fossil resources $(23 \%)$, the three eutrophication potential indicators together (12\%), and photochemical ozone creation potential (11\%), see Figure 2. Forty-six percent of the global warming potential and $49 \%$ of the abiotic depletion potential for fossil resources are caused by the landfilling of 683 tons of aggregate waste. Nineteen percent of the global warming potential and $21 \%$ of the abiotic depletion potential for fossil resources is caused by the production and combustion of diesel used in deconstruction.

Particulate matter emissions have the largest impact on the social dimension (56\% of the total impact), followed by the indicator "human toxicity-non-cancer effects" (35\%). Thirty-two percent 
of the particulate matter emissions is caused by the transport of 683 tons of aggregate waste, and $23 \%$ is caused by the production and combustion of diesel used during deconstruction of the bridge. Ninety percent of the impact of "human toxicity—non-cancer effects" is caused by the landfilling of aggregate waste.

In the economic dimension, for the indicator LCC and incomes, $93 \%$ of the total cost is for deconstruction workers. There is no income. For the indicator "environmental externalities", the largest part of the cost (52\%) comes from the landfilling of aggregate waste and the second largest $(20 \%)$ portion comes from the production and combustion of diesel used for deconstruction.

\subsubsection{Module D}

Regarding benefits and loads beyond the system boundary, the largest benefit in the environmental dimension is offered by the potential avoidance of contributing to global warming potential ( $45 \%$ of the total benefit) and the potential avoidance of contributing to the abiotic depletion potential for fossil resources (34\%), see Figure 2. The main part of this benefit is due to the potential re-use of aggregates.

The largest benefit in the social dimension is offered by the potential avoidance of particulate matter emissions (55\%) and the avoidance of ionizing radiation (21\%). Here, as well, the main part of this benefit is due to the potential re-use of aggregates.

In the economic dimension, for the indicator "LCC and incomes", $41 \%$ of the total income comes from the potential recycling of concrete as a filling material, and 37\% comes from the potential recycling of carbon steel reinforcement. For the indicator "environmental externalities", the largest benefit comes from the potential re-use of aggregates (48\%).

\subsection{Soil-Steel Composite Bridge Design Concept}

The results for each indicator used in the sustainability assessment of the SSC bridge per metre of bridge in units of measurement and per life cycle stage are presented in Table 7.

Table 7. Results for the SSC bridge design concept per indicator in units of measurement per life-cycle stage for the functional unit. Modules not assessed are abbreviated as "MNA".

\begin{tabular}{ccccccccc}
\hline Indicator & A0 & A1-A3 & A4-A5 & B1-B5 & B6-B7 & B8 & C1-C4 & D \\
\hline AP & MNA & 0.95 & 0.56 & 0.031 & 0 & 4.2 & 0.34 & -0.8 \\
ETP-fw & MNA & 1773 & 1571 & 89 & 0 & 4063 & 360 \\
SQP & MNA & 977 & 781 & 13 & 0 & 22,083 & 156 \\
GWP-total & MNA & 369 & 164 & 9.1 & 0 & 233 & 42 & -1348 \\
ADPE & MNA & $1.5 \times 10^{-2}$ & $1.4 \times 10^{-5}$ & $7.5 \times 10^{-7}$ & 0 & $5.4 \times 10^{-5}$ & $3.5 \times 10^{-6}$ & $-2.9 \times 10^{-5}$ \\
ADPF & MNA & 4667 & 2210 & 149 & 0 & 5222 & 554 & -3646 \\
EP-freshwater & MNA & $6.3 \times 10^{-4}$ & $5.0 \times 10^{-4}$ & $1.2 \times 10^{-5}$ & 0 & $3.1 \times 10^{-2}$ & $9.8 \times 10^{-5}$ & $-4.1 \times 10^{-4}$ \\
EP-marine & MNA & 0.24 & 0.25 & 0.0089 & 0 & 1.7 & 0.12 & -0.20 \\
EP-terrestrial & MNA & 2.6 & 2.8 & 0.10 & 0 & 20 & 1.4 \\
ODP & MNA & $3.8 \times 10^{-11}$ & $2.6 \times 10^{-11}$ & $2.3 \times 10^{-14}$ & 0 & $4.9 \times 10^{-10}$ & $8.5 \times 10^{-14}$ & $-1.5 \times 10^{-12}$ \\
POCP & MNA & 0.69 & 0.70 & 0.028 & 0 & 2.7 & 0.36 \\
PIR & MNA & 53 & 2.2 & 0.39 & 0 & 149 & 0.39 \\
HTP c & MNA & $2.9 \times 10^{-7}$ & $3.3 \times 10^{-8}$ & $9.4 \times 10^{-9}$ & 0 & $7.1 \times 10^{-7}$ & $2.8 \times 10^{-8}$ & -3.59 \\
HTP nc & MNA & $4.4 \times 10^{-6}$ & $1.9 \times 10^{-6}$ & $1.4 \times 10^{-7}$ & 0 & $1.1 \times 10^{-4}$ & $2.9 \times 10^{-6}$ & $-2.6 \times 10^{-7}$ \\
PM & MNA & $1.7 \times 10^{-5}$ & $9.6 \times 10^{-6}$ & $2.9 \times 10^{-7}$ & 0 & $4.1 \times 10^{-5}$ & $2.5 \times 10^{-6}$ & $-1.5 \times 10^{-5}$ \\
WDP & MNA & 53 & 1.9 & 0.47 & 0 & 109 & 2.5 & -48 \\
LCC and incomes & MNA & 295 & 99 & 16 & 0 & 86 & 10 & -0.8 \\
Environmental externalities & MNA & 1087 & 52 & 1.5 & 0 & 31 & -1.3 \\
\hline
\end{tabular}

The results for the SSC bridge are presented per life cycle stage in Table 6 . The results for the environmental and social dimensions are aggregated on the dimension level, while the results for the economic dimension are aggregated on the indicator level. The results for the environmental and social dimensions are normalized and weighted using the factors in Table 2, and the results for the economic indicators are summarized. Normalized and weighted results for the environmental and social dimensions per life cycle stage are presented per indicator in Figure 4 (only module B8) and Figure 5 (excluding module B8). Figure 6 shows the share of contribution of each resource to the total 
impact over the life cycle (modules A-C excluding B8) in the environmental dimension and the social dimension respectively, for the resources with the greatest contributions.

In the environmental dimension, $72 \%$ of the total impact for life cycle stages $\mathrm{A}-\mathrm{C}$ (excluding module B8) occurs in the production stage (modules A1-A3), followed by the construction stage (20\%, modules A4-A5). If module B8 was included, it would contribute to $38 \%$ of the total impact for life cycle stages A-C. Module D has the potential to reduce the future environmental impact (by future re-use or recycling) by $31 \%$ for life cycle stages $\mathrm{A}-\mathrm{C}$ (excluding module $\mathrm{B} 8$ ). The main contribution to the environmental impact over the life cycle (modules A-C, excluding B8) is accounted for by the indicators "abiotic depletion potential for non-fossil resources" (35\% of the total impact), "global warming potential" (30\% of the total impact), and "abiotic depletion potential for fossil resources" (19\% of the total impact). Practically all (99.6\%) of the abiotic depletion potential for non-fossil resources and $36 \%$ of the global warming potential are caused by the production of structural steel for the bridge. Forty-seven percent of the global warming potential is caused by the production and transport of aggregates. The production of structural steel for the bridge contributes to $54 \%$ and the production and transport of aggregates contributes to $30 \%$ of the total environmental impact over the life cycle (see Figure 6).

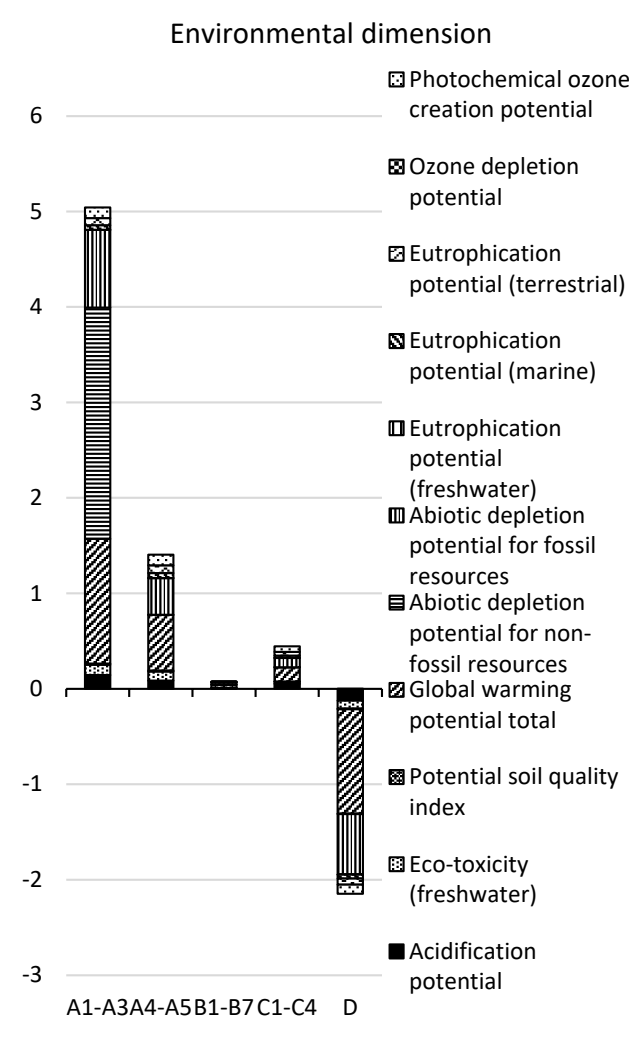

(a)

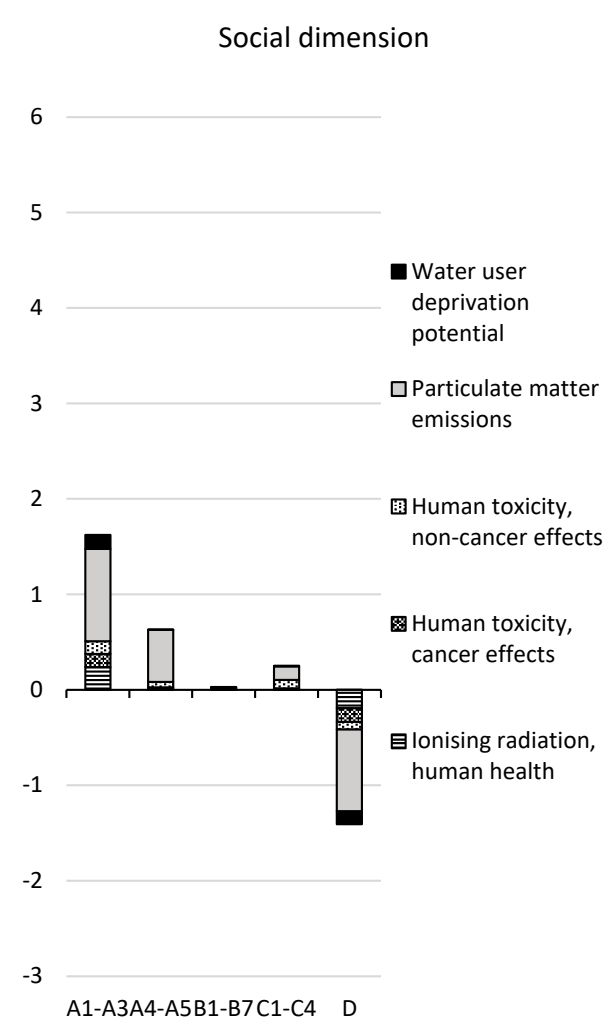

(b)

Figure 5. Normalized and weighted results for the SSC bridge design concept per life cycle stage in (a) the environmental dimension and (b) the social dimension per indicator and for the functional unit. Module B8 is not included. See Figure 4 for module B8. Note that the ozone depletion potential indicator bar cannot be seen in the figure since it is very small.

In the social dimension, $64 \%$ of the total impact of life cycle stages A-C (excluding module B8) occurs in the production stage, followed by the construction stage $(25 \%)$. If module B8 was included, it would contribute to $73 \%$ of the total impact for life cycle stages A-C. Module D presents the potential to reduce the future social impact by $56 \%$ for life cycle stages A-C (excluding module B8). The main contributor to the social impact over the life cycle (modules A-C excluding B8) is 
accounted for by the indicators "particulate matter emissions" (66\% of the total impact) and "human toxicity-non-cancer effects" (11\% of the total impact). The largest portion of the particulate matter emissions is caused equally by the production of aggregates and the production and combustion of diesel used for the construction, maintenance, and deconstruction of the bridge over the life cycle (each $36 \%$ ), followed by the production of structural steel (23\%). Over the life cycle, the production and transport of aggregates contributes to $44 \%$, the production of structural steel for the bridge contributes to $26 \%$ and the production and combustion of diesel used for the construction, maintenance, and deconstruction of the bridge over the life cycle contributes to $21 \%$ of the total social impact (see Figure 6).

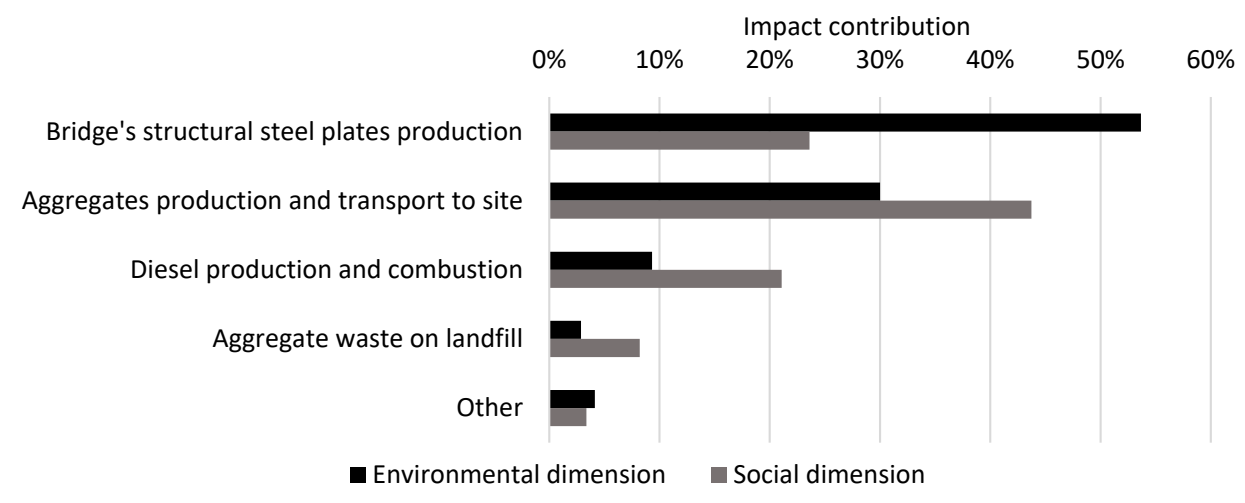

Figure 6. Contribution of resources to the total impact over the life cycle (modules A-C, excluding B8) for the SSC bridge design concept in the environmental and social dimensions.

In the economic dimension, $70 \%$ of the total net cost for the indicator "LCC and incomes" in life cycle in stages A-C (excluding module B8) occurs in the production stage, and $24 \%$ occurs in the construction stage (see Table 6). If module B8 was included, it would contribute to $17 \%$ of the total net cost for life cycle stages A-C. Module D presents the potential to reduce the future net cost (by future re-use or recycling) by $0.2 \%$ for life cycle stages $\mathrm{A}-\mathrm{C}$ (excluding module $\mathrm{B} 8$ ). The greatest contributor $(39 \%)$ to the cost of the LCC and incomes over the life cycle is the production of structural steel for the bridge. For the indicator environmental externalities, $68 \%$ of the total external cost in life cycle stages A-C (excluding module B8) occurs in the production stage. Ninety percent of the environmental externalities are caused by the production of structural steel for the bridge. If module B8 was included, it would contribute to $3 \%$ of the total external costs for life cycle stages A-C. Module D presents the potential to reduce the future external costs by $1 \%$ for life cycle stages $\mathrm{A}-\mathrm{C}$ (excluding module $\mathrm{B} 8$ ).

\subsubsection{Modules A1-A3}

In the production stage, the abiotic depletion potential for non-fossil resources has the largest impact in the environmental dimension (see Figure 5). This indicator has $48 \%$ of the total impact in this life cycle stage. Almost all (99.7\%) of the depletion is caused by the production of 40 tons of structural steel. The second largest contributor is the global warming potential; this constitutes $26 \%$ of the total environmental impact. Fifty-seven percent of this indicator is accounted for by the production of structural steel plates for the bridge and $42 \%$ by the production of aggregates. The abiotic depletion potential for fossil resources also has a significant impact ( $16 \%$ of the total environmental impact).

Particulate matter emissions have the largest impact in the social dimension (60\%). Fifty-eight of this originates from the production of aggregates and $40 \%$ comes from the production of bridge steel.

In the economic dimension, for the indicator "LCC and incomes", $67 \%$ of the total cost is for structural steel and $28 \%$ is for aggregates. There is no income. For the indicator "environmental externalities", $96 \%$ of the cost is for the production of structural steel. 


\subsubsection{Modules A4-A5}

In the construction stage, greenhouse gas emissions have the largest impact in the environmental dimension (see Figure 5). The global warming potential contributes to $41 \%$ of the total impact in this life cycle stage. Seventy-three percent of this originates from the transport of aggregates to the construction site. Nineteen percent originates from the production and combustion of diesel used in construction machines on the construction site. The second largest impact comes from the abiotic depletion potential for fossil resources, causing $27 \%$ of the total environmental impact. Seventy-two percent of this is caused by the transport of aggregates to the site. The three eutrophication potential indicators make a significant contribution, together contributing to $9 \%$ of the total environmental impact. The production and combustion of diesel used at the construction site contributes to $71 \%$ of the total eutrophication potential.

In the social dimension, particulate matter emissions have the largest impact by far $(86 \%)$. Eighty-seven percent of these emissions are caused by the production and combustion of diesel used at the construction site.

In the economic dimension, for the indicator "LCC and incomes", 32\% of the total cost is for the transport of aggregates, $28 \%$ is for the construction workers, and $20 \%$ is for transport of the bridge's structural steel plates. There is no income. For the indicator "environmental externalities", $66 \%$ of the total cost is for the transport of aggregates and $27 \%$ is for the production and combustion of diesel used at the construction site.

\subsubsection{Modules B1-B7}

In the use stage, greenhouse gas emissions have the largest impact in the environmental dimension $(42 \%)$, followed by the depletion of fossil resources (33\%) (see Figure 5). Seventy-three percent of the global warming potential is caused by the production of 1.4 tons of steel racks and $16 \%$ is caused by the production of 10.5 tons of asphalt. Fifty percent of the abiotic depletion potential of fossil resources is caused by the production of asphalt and $41 \%$ is caused by the production of steel racks.

In the social dimension, particulate matter emissions have the greatest impact (59\% of the total impact), followed by $16 \%$ each from the indicators "human toxicity-cancer effects" and "human toxicity-non-cancer effects". Seventy-six percent of particulate matter emissions comes from the production of steel racks. The production of steel racks contributes to $87 \%$ of the factor "human toxicity-cancer effects" and 55\% of "human toxicity-non-cancer effects". The production of asphalt contributes to $31 \%$ of "human toxicity-non-cancer effects".

In the economic dimension, for the indicator "LCC and incomes", $50 \%$ of the total cost is for steel racks. The installation of steel racks accounts for $23 \%$ of the total cost. There is no income. For the indicator "environmental externalities", $81 \%$ of the total cost is for the production of steel racks.

\subsubsection{Module B8}

The environmental impact of module B8, the stage relating to the user's utilization, is $38 \%$ lower than the environmental impact of all other modules together (excluding module D) for the SSC bridge, see Table 6. The social impact of module B8 is almost three times larger. The net cost for LCC and incomes is $80 \%$ lower for module B8 than for all other modules together (excluding module D). The "environmental externalities" indicator is 97\% lower for module B8 than for all other modules together (excluding module D). For other aspects of module B8 that do not depend on the bridge type, see Section 3.1.4.

\subsubsection{Modules C1-C4}

In the end-of-life stage, global warming potential has the largest impact in the environmental dimension (34\%), followed by the abiotic depletion potential for fossil resources $(22 \%)$, the three eutrophication potential indicators together $(14 \%)$, and the photochemical ozone creation potential 
$(12 \%)$, see Figure 5 . Fifty-one percent of both the global warming potential and the abiotic depletion potential for fossil resources is caused by the landfilling of 683 tons of aggregate waste. Thirty-three percent of the global warming potential is caused by the production and combustion of diesel used for deconstruction. Thirty-four percent of the abiotic depletion potential for fossil resources is caused by the production of diesel used for deconstruction.

In the social dimension, particulate matter emissions have the greatest impact ( $56 \%$ of the total impact), followed by the indicator "human toxicity-non-cancer effects" $(35 \%)$. Seventy-seven percent of particulate matter emissions and $90 \%$ of human toxicity-non-cancer effects are caused by the landfilling of aggregate waste.

In the economic dimension, for the indicator "LCC and incomes", $90 \%$ of the total cost is for deconstruction workers. There is no income. For the indicator "environmental externalities", the largest portion of the cost (55\%) comes from the landfilling of aggregate waste and the second largest portion $(33 \%)$ comes from the production and combustion of diesel used for deconstruction.

\subsubsection{Module D}

Regarding the benefits and loads beyond the system boundary, the largest potential future benefit in the environmental dimension is the avoidance of contributing to global warming potential ( $51 \%$ of the total benefit) and the avoidance of abiotic depletion for fossil resources (30\%), see Figure 5 . The main factors involved in the avoidance of contributing to global warming potential are the potential recycling of bridge steel (52\%) and the potential re-use of aggregates $(45 \%)$.

Table 8. Comparison of the design concepts for modules A-C and for module D for the functional unit. The results are aggregated at the dimension level for the environmental and social dimensions and at the indicator level for the economic dimension. The results for the environmental and social dimensions are normalized and weighted, while the results for the economic dimension are summarized. Module B8 is not included in the comparison. The best options are highlighted in grey.

\begin{tabular}{ccccc}
\hline Dimension, Indicator (unit) & \multicolumn{2}{c}{ CSF Bridge } & \multicolumn{2}{c}{ SSC Bridge } \\
\cline { 2 - 5 } & A-C & D & A-C & D \\
\hline Environmental, all (dimensionless) & 4.4 & -1.5 & 7.0 & -2.1 \\
Social, all (dimensionless) & 3.5 & -1.2 & 2.5 & -1.4 \\
Economic, LCC and incomes (Euro) & 526 & -1.1 & 421 & -0.8 \\
Economic, Environmental externalities (Euro) & 182 & -7.9 & 1142 & -14 \\
\hline
\end{tabular}

The greatest potential future benefits in the social dimension are the avoidance of particulate matter emissions $(61 \%)$ and the avoidance of ionising radiation-human health $(14 \%)$. The main factors involved in the avoidance of particulate matter emissions are the potential re-use of aggregates (59\%) and the potential recycling of bridge steel (39\%).

In the economic dimension, for the indicator "LCC and incomes", $94 \%$ of the total income comes from the potential recycling of the bridge's structural steel plates. For the indicator "environmental externalities", the largest benefit comes from the potential recycling of the bridge's structural steel plates $(70 \%)$.

\subsection{Comparison of the Design Concepts}

A comparison of the two design concepts over the life cycle (modules A-C excluding module B8) and in terms of the future re-use, recovery, and recycling potential (module D) is presented in Table 8 and Figures 7-9. The results are aggregated on the dimension level for the environmental and social dimensions and on the indicator level for the economic dimension. The results for the environmental and social dimensions are normalized and weighted, and the results for the economic dimension are summarized. The results for the environmental and social dimensions per life cycle stage for the two concepts are presented in Figure 10, and the summarized results for the economic indicators are presented in Figure 11 (excluding module B8). 


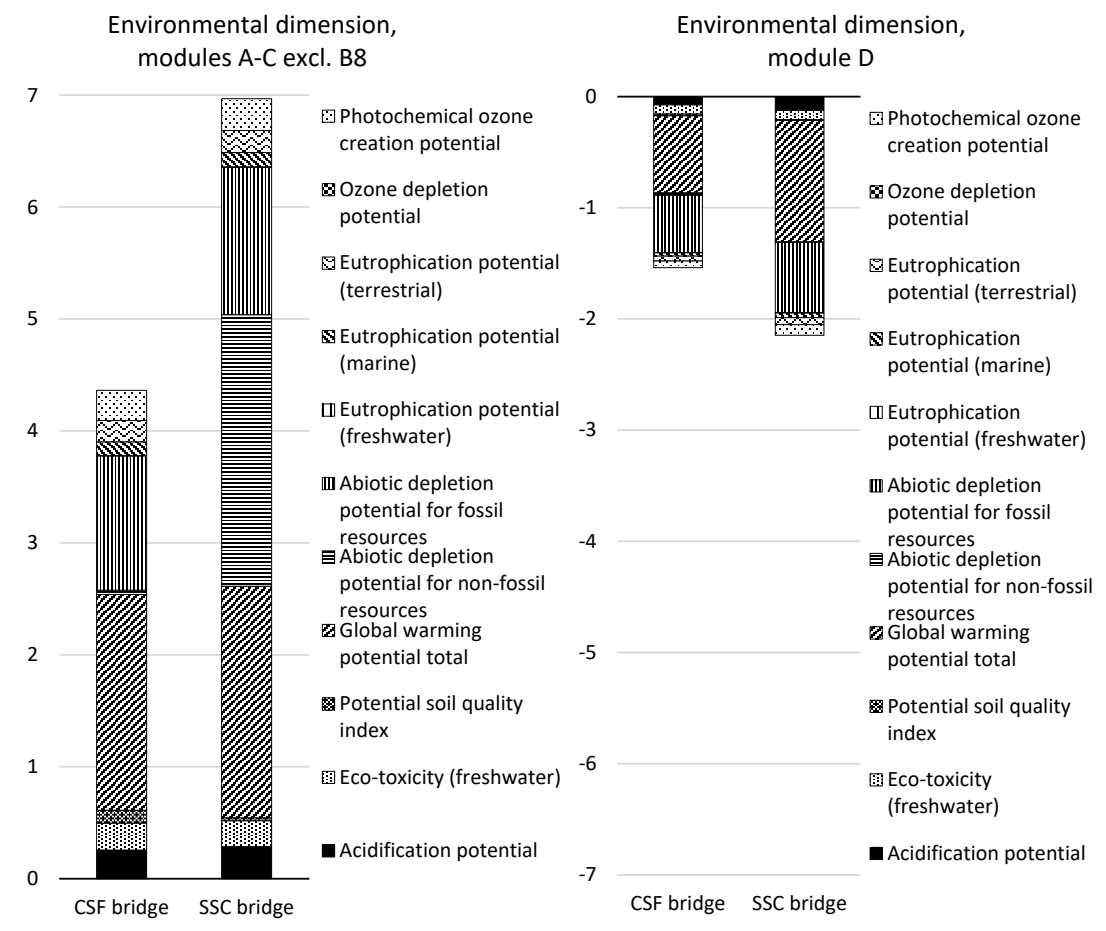

(a)

(b)

Figure 7. Comparison of the design concepts in the environmental dimension for (a) life cycle stages $\mathrm{A}-\mathrm{C}$ excluding module B8 and (b) module D per indicator and for the functional unit. Note that the ozone depletion potential indicator bar cannot be seen in the figure since it is very small.

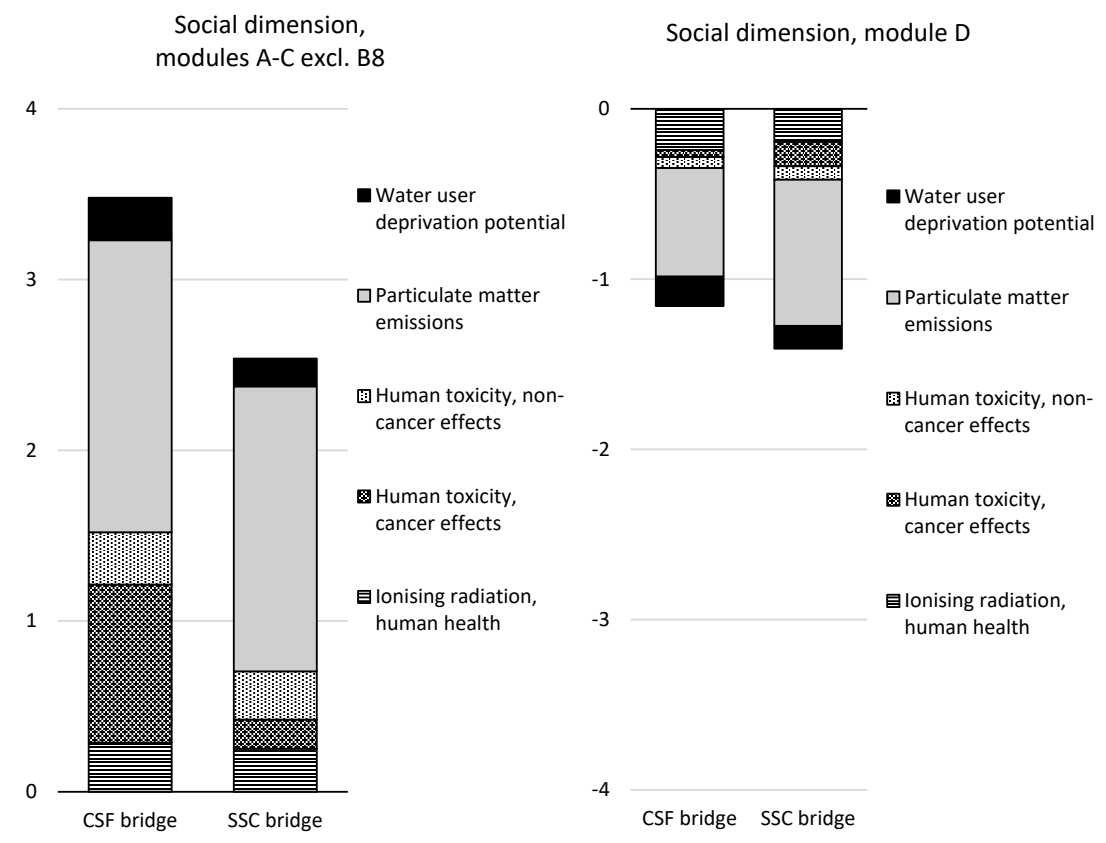

(a)

(b)

Figure 8. Comparison of the design concepts in the social dimension for (a) life cycle stages A-C excluding module B8 and (b) module D per indicator and for the functional unit. 


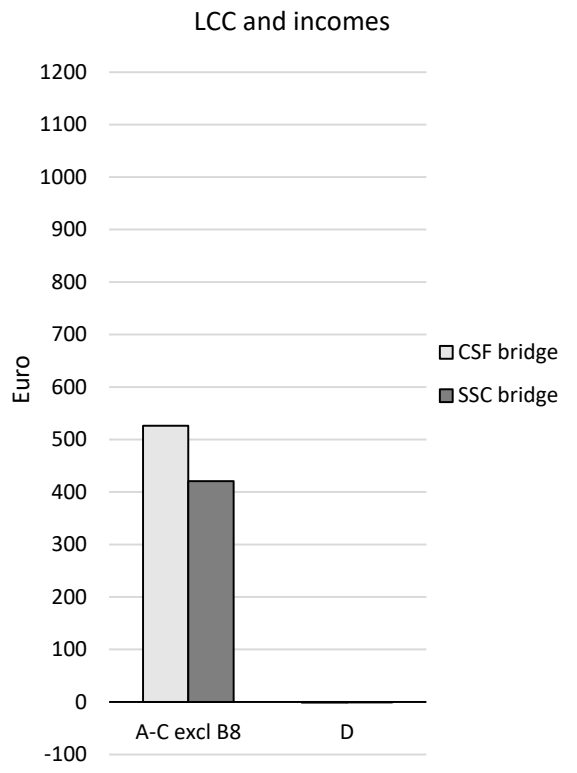

(a)

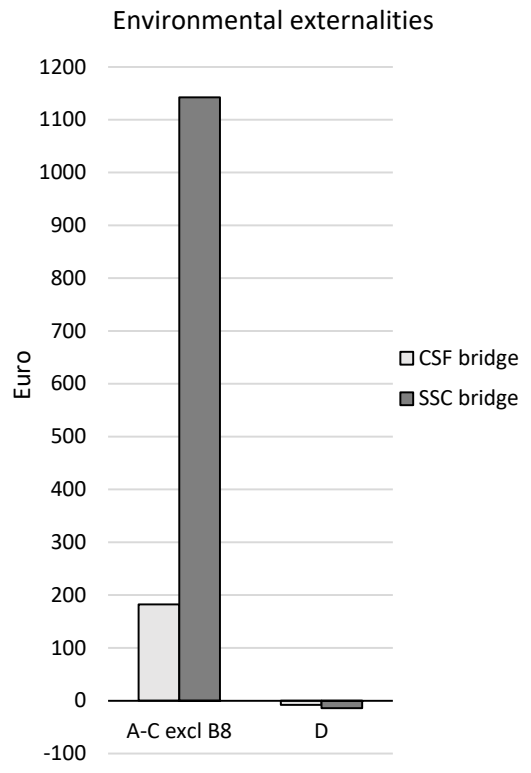

(b)

Figure 9. Comparison of the design concepts per life cycle stage for (a) the LCC and incomes and (b) the environmental externalities; presented in Euros for the functional unit. Module B8 is not included in the comparison.

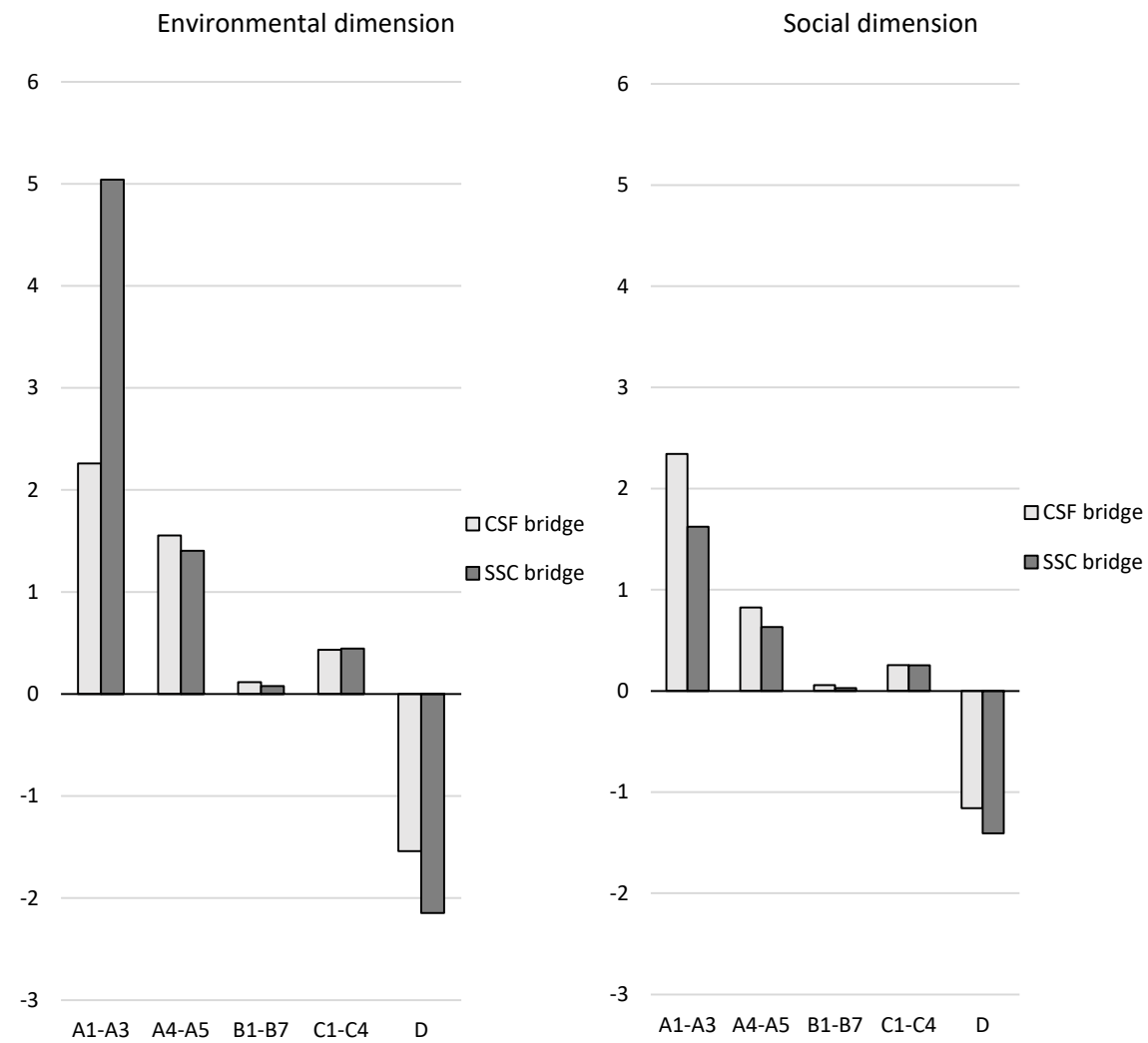

(a)

(b)

Figure 10. Comparison of the design concepts per life cycle stage in (a) the environmental dimension and (b) the social dimension for the functional unit. Module B8 is not included in the comparison. 
In the environmental dimension, the CSF bridge performs better than the SSC bridge over the life cycle (see Table 8 and Figure 7). The environmental impact of the CSF bridge is approximately one-third lower than that of the SSC bridge. After the end-of-life stage (in module D), the potential avoidance of a negative environmental impact is 39\% greater for the SSC bridge.

In the social dimension, the SSC bridge performs better than the CSF bridge over the life cycle (see Table 8 and Figure 8). The social impact of the SSC bridge is 27\% lower than that of the CSF bridge. After the end-of-life stage (in module D), the potential avoidance of negative social impact is $22 \%$ greater for the SSC bridge.

In the economic dimension, the SSC bridge performs better than the CSF bridge over the life cycle for the indicator "LCC and incomes", but it has a significantly worse performance than the CSF bridge for the indicator "environmental externalities" (see Table 8 and Figure 9). The net cost of the SSC bridge is $20 \%$ lower than that of the CSF bridge when it comes to the indicator "LCC and incomes". In contrast, the impact of the factor "environmental externalities" is six times greater for the SSC bridge than for the CSF bridge. After the end-of-life stage (in module D), the potential income and the avoidance of environmental externalities have very small impacts for both concepts.

Considering the different life cycle stages, the SSC bridge has double the environmental impact in the material production phase (modules A1-A3) compared with the CSF bridge (see Figure 10). This is mainly due to the abiotic depletion potential of non-fossil resources caused by the manufacture of structural steel plates for the SSC bridge. This indicator contributes to almost half of the total environmental impact of the SSC bridge in the production stage (see Figure 7). The indicator global warming potential contributes to one-quarter of the environmental impact of the SSC bridge in the production stage.

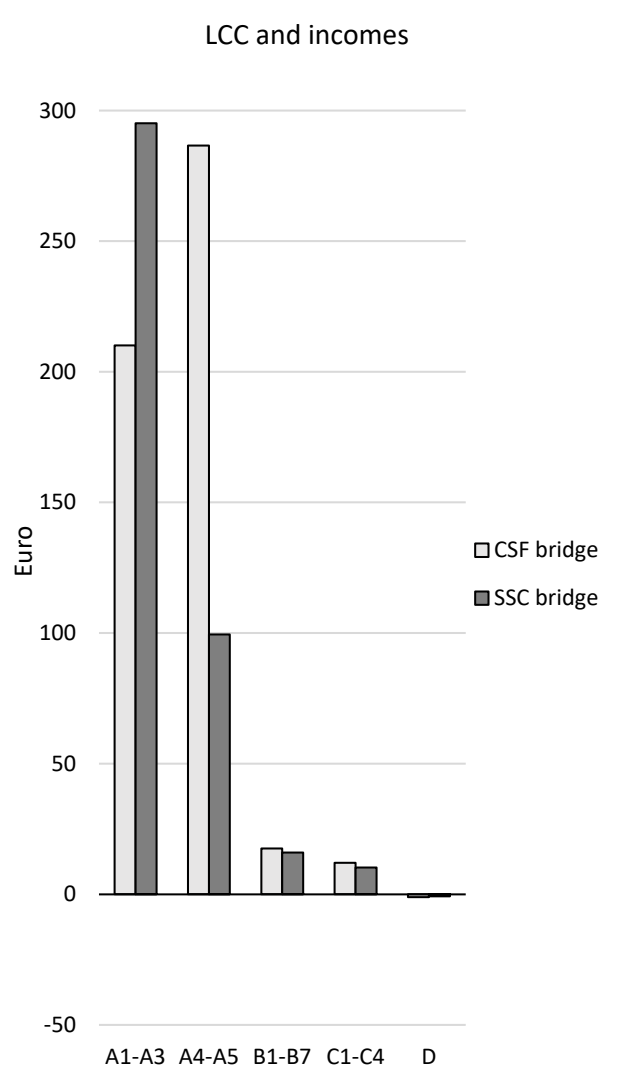

(a)

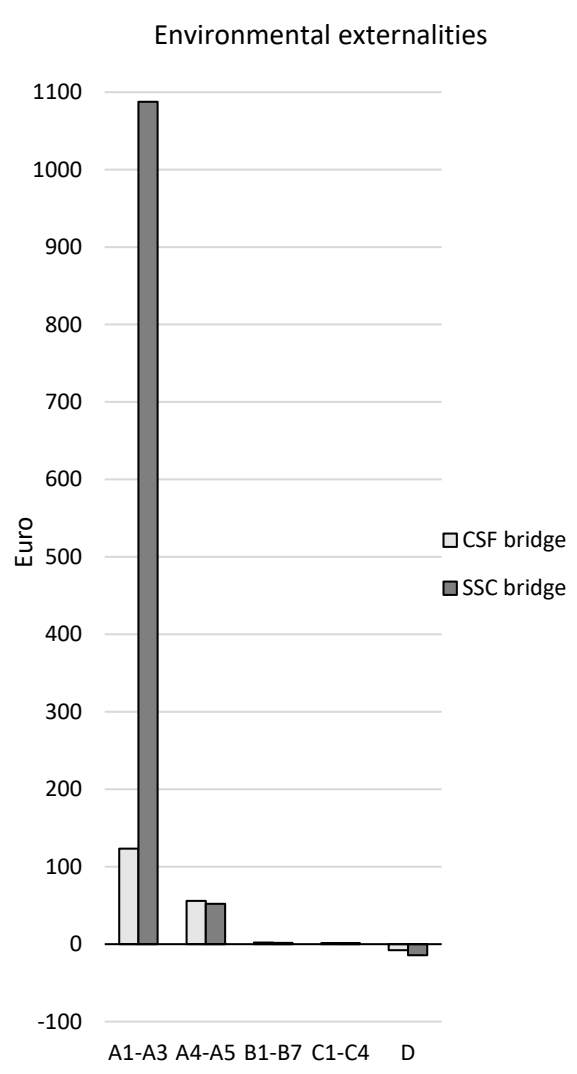

(b)

Figure 11. Comparison of the design concepts per life cycle stage for (a) the LCC and incomes and for (b) the environmental externalities presented in Euros for the functional unit. Module B8 is not included in the comparison. Note the different $y$-axis scales in the charts. 
The CSF bridge has a $44 \%$ larger social impact in the material production phase than the SSC bridge (see Figure 10). This is primarily due to "human toxicity—cancer effects", which are mainly caused by production of stainless-steel reinforcement, and the particulate matter emissions, which are mainly caused by the production of aggregates.

In the production stage, the impact of the environmental externalities of the SSC bridge is almost nine times greater than that of the CSF bridge (see Figure 11). This is due to the use of non-renewable elements in the production of the bridge's structural steel plates. In the construction stage, the net cost for LCC and incomes is almost three times larger for the CSF bridge. This is because of the larger cost for construction workers for the CSF bridge compared with the SSC bridge.

\section{Discussion}

In the environmental dimension, the CSF bridge was found to perform better than the SSC bridge over the life cycle (see Table 8 and Figure 7). The environmental impact of the CSF bridge was 37\% lower than that of the SSC bridge. Similar results were demonstrated in an LCA study comparing a steel box girder bridge and a concrete box girder bridge, where the concrete bridge alternative performed best environmentally overall [22]. However, another LCA study on four CSF bridges and four SSC bridges showed the opposite result: the SSC bridges performed better than the CSF bridges over the life cycle [23]. This is partly because only $54-74 \%$ of the structural steel mass was used in three of the SSC bridges in the study by [23], compared with the SSC bridge in this case study. It is also partly because $37 \%$ of the structural steel plates were assumed to be secondary steel produced in an electric arc furnace (EAF) route in [23], while in this case study, all of the structural steel plates are from primary steel produced through a blast furnace $(\mathrm{BF})$ route.

In the social dimension, the SSC bridge was found to perform better than the CSF bridge over the life cycle (see Table 8 and Figure 8). The social impact of the SSC bridge was $27 \%$ lower than that of the CSF bridge. A similar result was demonstrated by [23], where particulate matter emissions were slightly lower for three of the SSC bridges compared with the CSF bridges.

In the economic dimension, the SSC bridge was found to perform better than the CSF bridge over the life cycle for the indicator LCC and incomes, but it performed significantly worse than the CSF bridge for the indicator environmental externalities (see Table 8 and Figure 9). The opposite result was shown for environmental externalities in [23]. Using the Ecotax02 and Ecovalue08 monetary weighting methods updated with the Ecovalue12 method indicators [24,25], the SSC bridges performed better than the CSF bridges. This might be explained by the fact that the depletion of abiotic resources indicator was not included in the calculation of environmental externalities in [23], even though it is part of both the Ecotax02 and the Ecovalue 08 and Ecovalue12 methods. Non-renewable elements and non-renewable energy resources were found to be the major contributors contribute to the environmental externalities in this case study.

For both design concepts, the majority of the negative impact on sustainability was found to occur in the production stage (modules A1-A3). This was also shown in [23], where between 55\% and $92 \%$ of the environmental impact occurred in the production stage, depending on the indicator. An LCA study of a steel box girder bridge and a concrete box girder bridge similarly showed that the production of materials for the bridge superstructure and the abutments accounted for the main share of the environmental impact, with a limited number of materials being important [22].

Furthermore, the case study demonstrated that $36 \%$ of the life-cycle environmental impact for the CSF bridge and $20 \%$ for the SSC bridge occurred in the construction stage (modules A4-A5). In [23], it was also shown that the environmental impact of the construction stage is significant; causing up to $34 \%$ of the life cycle impact for some indicators. However, in [22], the construction phase accounted for a relatively small part of the impact, and the use phase contributed more significantly, which is contrary to the results of this case study. A main difference between the two concepts in this case study is that a large part of the economic impact (LCC and incomes) was found to occur in the construction stage for the CSF bridge, and this was mainly due to the cost of construction workers. 
Module B8 was found to contribute to $50 \%$ and $38 \%$ of the total environmental impact and $66 \%$ and $73 \%$ of the total social impact over the life cycle (modules A-C) for the CSF bridge and SSC bridge, respectively. This demonstrates that the environmental and social impacts of the bridge itself are, in fact, significant in comparison to the impact from traffic on the bridge. This was even more obvious for the economic impacts, as module B8 was shown to only contribute to between $3 \%$ and $17 \%$ for the two economic indicators considered for both bridge types.

The main contribution to the environmental impact over the life cycle (modules A-C excluding B8) was shown to come from the indicator abiotic depletion potential for non-fossil resources for the SSC bridge $(35 \%)$ and the indicator global warming potential for the CSF bridge (44\%). Similar results were demonstrated in an LCA study of a concrete box girder bridge and a steel box girder bridge where global warming, abiotic depletion, and acidification were found to be the indicators with the greatest contributions [22]. In [23], on the contrary, it was shown that the SSC bridges performed better than the CSF bridges regarding the indicator global warming potential. This was partly because less structural steel was used in the SSC bridges and because $37 \%$ of the structural steel plates were assumed to be secondary steel produced via an EAF route in [23] (see further explanation above). If only the indicator "global warming potential" had been considered in this case study, the SSC bridge would have performed only $7 \%$ worse than the CSF bridge in the environmental dimension. When considering all environmental indicators, the SSC bridge was found to perform $60 \%$ worse in the environmental dimension. This demonstrates the importance of including more indicators than only global warming potential, as shown in previous studies [26]. This is an important observation, as today, it is common practice to solely consider global warming potential (or one other indicator such as embodied energy) in assessments of environmental performance $[9,26,27]$.

The main contributor to the social impact over the life cycle (modules A-C excluding B8) was shown to be the indicator particulate matter emissions for both concepts. This is, in part, because of the large weight given to this indicator, but also because construction activities are significant sources of particulate matter emissions, for example, when crushing aggregates [28,29]. For the CSF bridge, the indicator "human toxicity-cancer effects" was also shown to contribute to a large portion of the social impact. For the CSF bridge, it was shown that approximately one-third of the particulate matter emissions were caused by the production of aggregates and their transport to the construction site, and one-third were caused by the production and combustion of diesel used at the construction site. For the SSC bridge, it was shown that one-third of the particulate matter emissions were caused by the production of aggregates; one-third by the production and combustion of diesel used for the construction, maintenance, and deconstruction of the bridge over the life cycle; and one-quarter by the production of structural steel.

The net cost for the LCC and incomes indicator was found to be $25 \%$ higher for the CSF bridge than the SSC bridge over the life cycle. For the CSF bridge, the main costs came from cost for workers during construction, and the production and transport of aggregates, concrete, and reinforcement steel. For the SSC bridge, the main contributor to the cost of the LCC and incomes was the cost for the production of structural steel. The environmental externalities of the SSC bridge was six times greater than that of the CSF bridge over the life cycle because of the use of non-renewable elements in the production of the bridge's structural steel plates.

The production of aggregates and their transport to the construction site was shown to be the main factor in the environmental and social impacts of the CSF bridge and the social impact of the SSC bridge. It was also shown to be the second greatest factor in the environmental impact of the SSC bridge. Hence, there is great potential to reduce environmental and social impacts by re-using aggregates on site in the next life cycle to avoid the production of virgin aggregates and their transport to the construction site. The production of the bridge's structural steel plates plays the largest role in the environmental impact as well as the impact on environmental externalities for the SSC bridge due to the depletion of metals. Thus, there is great potential to reduce the impact by using steel produced from recycled steel. Regarding the LCC and incomes over the life cycle, the results show that costs can be reduced 
by lowering the work costs as well as the material costs for the materials purchased in large quantities, such as aggregates, steel and concrete.

It is important to keep in mind that the environmental and social impact results are highly dependent on the LCA datasets chosen for the calculations. It is possible to apply the method using generic licensed datasets or generic datasets from open online LCA databases or Environmental Product Declarations (EPDs), provided they follow the EN15804 + A2 standard. The use of supplier EPDs instead of generic datasets further increases the accuracy of the environmental and social assessment results, since EPDs contain supplier-specific declarations, while generic datasets may not be fully representative of the actual materials supplied in an assessed civil engineering works project. In this case study, only generic datasets were used. They are not completely representative of the resources purchased for the object of assessment. For example, the generic dataset used for aggregates differed from the aggregates purchased, especially regarding the distance between the mining site and crushing plant (10 km in the generic dataset, a few hundred metres for the actual supplier). Generic datasets were used because supplier specific EPDs that follow the EN15804 + A2 standard are not yet available.

As shown from the examination of results, this method allows the sustainability performance of design concepts to be compared at the life cycle stage and construction component level in the early design and planning stages. The data available in these early stages are sufficient for assessment. Through the examination possibilities made available by the transparency of the method, it is possible to identify the critical elements in a civil engineering works project with the greatest impacts on sustainability. This allows necessary adjustments to be made to achieve more sustainable design concepts. Due to its general character, the method can be applied to other types of civil engineering works, not only bridges.

For the social dimension, in particular, but also for the environmental dimension, further research is needed to define appropriate indicators for civil engineering projects. The sustainability dimensions could also be further aggregated using a multi-criteria decision analysis (MCDA) method to obtain an overall sustainability score [30-32]. Furthermore, scenarios for the construction, use, and end-of-life stages may be improved by collecting data from ongoing projects [5]. It is recommended that future studies carry out a sensitivity analysis to assess the influences of different scenarios and datasets whose uncertainty is considered important for the evaluated impacts.

\section{Conclusions}

The case study demonstrates that our method can be used to carry out comparable and transparent life cycle sustainability performance assessments in the early design and planning stages of a civil engineering works project. It allows the sustainability performance of design concepts to be compared at the life cycle stage and construction component level. The method enables the identification of critical indicators with the greatest impacts on sustainability at the different life cycle stages and for the critical elements. The method is transparent, because the underlying BOMs, scenarios, and datasets used for the assessment are clearly described, and the results can be evaluated down to the building material level. Since the method is based on quantitative indicators and fixed factors, the calculation process used in the assessment is automatable.

The use of supplier EPDs instead of generic datasets will further increase the accuracy of the environmental and social assessment results, since EPDs are supplier-specific declarations, while generic datasets may not be fully representative of the actual materials supplied in an assessed civil engineering works project.

The case study demonstrates the importance of including more indicators than global warming potential in environmental assessments. Environmental and sustainability performance is clearly dependent on several indicators, and care should be exercised when generalising results obtained in assessments that only take into account only one or a few indicators. 
The method used in the case study includes state-of-the-art indicators according to current standard specifications and can be complemented with additional indicators. For the social dimension, in particular, but also for the environmental dimension, further research is needed to define appropriate indicators for civil engineering projects.

The results of the case study show the importance of the production stage (modules A1-A3) and the construction stage (modules A4-A5) on the sustainability performance over the life cycle. Production of structural steel for the SSC bridge has the greatest environmental impact and accounts for almost all of the environmental externalities, which explains the poorer performance of this bridge in the environmental dimension. However, the CSF bridge was shown to perform worse than the SSC bridge in the social dimension with a higher LCC. The former point can be mainly explained by the large global warming potential of the CSF bridge due to concrete production, and the latter point can be explained by higher costs during construction due to being more labour-intensive. The production and transport of aggregates have large negative environmental and social impacts for both bridge types.

In summary, the examination of the case study assessment results provides important knowledge on the indicators and life cycle stages associated with large sustainability impacts for each of the bridge concepts investigated. We conclude that to reduce the overall negative impact on sustainability, mitigation measures should primarily address the production and construction stages. Our findings contribute to the development of a better understanding of the sustainability impact of civil engineering works through the identification of elements with the greatest impacts. A special focus and adaptations of identified elements (e.g., origin and type of materials, equipment used, structural optimization) could significantly improve the sustainability performance of the design concepts. After necessary adaptations have been applied to a design concept, the assessment can be re-performed to assess the new conditions. If the assessment is automated, this step could be iterated until the most sustainable alternative is found.

Author Contributions: Conceptualization, K.E., A.M., M.K. and R.R.; methodology, K.E.; software, K.E.; validation, A.M. and M.K.; formal analysis, K.E. and A.M.; investigation, K.E. and A.M.; data curation, K.E.; writing-original draft preparation, K.E.; writing-review and editing, K.E., A.M. and P.B.; visualization, K.E.; supervision, R.R., M.K. and M.N.; project administration, R.R. and M.K.; funding acquisition, R.R. All authors have read and agreed to the published version of the manuscript.

Funding: This research was funded by VINNOVA and the Swedish Transport Administration, grant number 2017-03312 and 2017-037 respectively.

Acknowledgments: Case study data were provided by project manager Sonja Högvall, NCC.

Conflicts of Interest: The authors declare no conflict of interest.

\section{Appendix A}

The life cycle inventory (LCI) database provides the life cycle inventory data. The datasets used in the life cycle assessment (LCA) modelling are presented in Table A1.

Table A1. Assignments of inputs and outputs to LCIs from the GaBi database for the LCA.

\begin{tabular}{|c|c|c|c|c|c|}
\hline Inventory & Description & Assumption & GaBi Dataset & Country & Source \\
\hline Acetylene & Acetylene & - & Ethine (acetylene) & $\mathrm{DE}$ & $\begin{array}{l}\text { Generic dataset } \\
\text { from Sphera }\end{array}$ \\
\hline \multirow{2}{*}{$\begin{array}{l}\text { Aggregate waste } \\
\text { treatment }\end{array}$} & \multirow{2}{*}{$\begin{array}{l}\text { Aggregate and } \\
\text { macadam waste }\end{array}$} & \multirow{2}{*}{$\begin{array}{c}90 \% \text { is re-used as aggregates } \\
\text { on site, } 10 \% \text { is transported to } \\
\text { landfill }\end{array}$} & $\begin{array}{l}\text { Crushed stone grain } \\
\text { 2-15 mm (undried) } \\
\text { (EN15804 A1-A3) }\end{array}$ & EU-28 & " \\
\hline & & & $\begin{array}{c}\text { Inert matter } \\
\text { (Construction waste) } \\
\text { on landfill }\end{array}$ & $\mathrm{DE}$ & “ \\
\hline $\begin{array}{l}\text { Aggregates 0/16 } \\
\text { and } 0 / 90 \mathrm{~mm}\end{array}$ & $\begin{array}{c}\text { Crushed } \\
\text { aggregates 0/16 } \\
\text { and 0/90 from } \\
\text { igneous rock } \\
\text { in Sweden }\end{array}$ & $\begin{array}{l}\text { European limestone } 2 / 15 \mathrm{~mm} \\
\text { crushed stone }\end{array}$ & $\begin{array}{l}\text { Crushed stone grain } \\
\text { 2-15 mm (undried) } \\
\text { (EN15804 A1-A3) }\end{array}$ & EU-28 & " \\
\hline
\end{tabular}


Table A1. Cont.

\begin{tabular}{|c|c|c|c|c|c|}
\hline Inventory & Description & Assumption & GaBi Dataset & Country & Source \\
\hline Asphalt $\mathrm{ABb}$ & $\begin{array}{l}\mathrm{ABb} \text { asphalt } \\
\text { from Sweden }\end{array}$ & $\begin{array}{c}\text { European average supporting } \\
\text { layer asphalt }\end{array}$ & $\begin{array}{c}\text { Asphalt supporting } \\
\text { layer (EN15804 } \\
\text { A1-A3) }\end{array}$ & EU-28 & “ \\
\hline Asphalt ABT & $\begin{array}{l}\text { ABT asphalt } \\
\text { from Sweden }\end{array}$ & $\begin{array}{c}\text { European average asphalt } \\
\text { pavement }\end{array}$ & $\begin{array}{l}\text { Asphalt pavement } \\
\text { (EN15804 A1-A3) }\end{array}$ & EU-28 & " \\
\hline \multirow[b]{2}{*}{ Asphalt recycling } & \multirow{2}{*}{$\begin{array}{l}\text { Recycling of } \mathrm{ABb}, \\
\text { ABT, and } \\
\text { Viacogrip asphalt }\end{array}$} & \multirow{2}{*}{$\begin{array}{l}0.7 \mathrm{kWh} \text { of Swedish grid mix } \\
\text { electricity used per ton of recycled } \\
\text { asphalt (crushing). } 1000 \mathrm{~kg} \\
\text { of recycled asphalt replaces } 740 \mathrm{~kg} \\
\text { of virgin aggregates and } 60 \mathrm{~kg} \\
\text { of virgin bitumen. }\end{array}$} & $\begin{array}{l}\text { Crushed stone grain } \\
2-15 \mathrm{~mm} \text { (undried) } \\
\text { (EN15804 A1-A3) }\end{array}$ & $\mathrm{DE}$ & “ \\
\hline & & & $\begin{array}{l}\text { Bitumen (Eurobitume } \\
\text { LCI report 2019) w } \\
\text { infrastructure }\end{array}$ & EU-28 & $\begin{array}{c}\text { Generic dataset } \\
\text { based } \\
\text { on Eurobitume } \\
\text { report 2019 [33] }\end{array}$ \\
\hline Asphalt ViacoGrip & $\begin{array}{l}\text { ViacoGrip } \\
\text { asphalt from } \\
\text { Sweden }\end{array}$ & European average SMA asphalt & $\begin{array}{c}\text { Stone mastic asphalt } \\
\text { SMA (EN15804 } \\
\text { A1-A3) }\end{array}$ & EU-28 & $\begin{array}{l}\text { Generic dataset } \\
\text { from Sphera }\end{array}$ \\
\hline $\begin{array}{c}\text { Average } \\
\text { electricity/diesel } \\
\text { driven train }\end{array}$ & - & - & $\begin{array}{l}\text { Rail transport } \\
\text { cargo-average, } \\
\text { average train, gross } \\
\text { tonne weight } 1000 \\
\text { t/726 t payload } \\
\text { capacity }\end{array}$ & GLO & " \\
\hline Bitumen sealant & & & $\begin{array}{l}\text { Bitumen emulsion (EN } \\
15804 \text { A1-A3) }\end{array}$ & $\mathrm{DE}$ & $"$ \\
\hline Bitumen sheet & $\begin{array}{l}\text { Icopal Membrane } \\
\text { 5BRO (YEP 6500) }\end{array}$ & Produced in Germany & $\begin{array}{l}\text { Bitumen sheets } \\
\text { PYE-PV } 200 \text { S5 ns } \\
\text { (slated) (EN15804 } \\
\text { A1-A3) }\end{array}$ & $\mathrm{DE}$ & “ \\
\hline $\begin{array}{l}\text { Bitumen sheet } \\
\text { waste }\end{array}$ & $\begin{array}{l}\text { Incineration in } \\
\text { Swedish district } \\
\text { heating plant } \\
\text { (Jönköping) }\end{array}$ & $\begin{array}{l}\text { Incineration of average municipal } \\
\text { solid waste (MSW) in Germany }\end{array}$ & $\begin{array}{l}\text { Commercial waste } \\
\text { in municipal waste } \\
\text { incineration plant }\end{array}$ & $\mathrm{DE}$ & “ \\
\hline Bituprimer & Degadur ${ }^{\circledR} 112$ & - & $\begin{array}{l}\text { Methacrylate resin } \\
\text { products, highly-filled, } \\
\text { flow } \\
\text { coatings-Deutsche } \\
\text { Bauchemie e.V. } \\
\text { (DBC) (A1-A3) }\end{array}$ & $\mathrm{DE}$ & “ \\
\hline $\begin{array}{l}\text { Carbon steel } \\
\text { reinforcement } \\
\text { recycling }\end{array}$ & - & Average German production & $\begin{array}{l}\text { Recycling potential } \\
\text { steel profile (D) }\end{array}$ & $\mathrm{DE}$ & " \\
\hline Concrete elements & $\begin{array}{l}\text { Concrete } \\
\text { kerbstone }\end{array}$ & Bricks of concrete C20/25 & $\begin{array}{l}\text { Concrete bricks } \\
\text { (EN15804 A1-A3) }\end{array}$ & $\mathrm{DE}$ & “ \\
\hline $\begin{array}{l}\text { Concrete waste } \\
\text { treatment }\end{array}$ & - & $\begin{array}{l}0.7 \mathrm{kWh} \text { of Swedish grid mix } \\
\text { electricity used per ton of recycled } \\
\text { concrete (crushing). } 1 \mathrm{~kg} \\
\text { of recycled concrete replaces } 1 \mathrm{~kg} \\
\text { of virgin aggregates. }\end{array}$ & $\begin{array}{l}\text { Crushed stone grain } \\
2-15 \mathrm{~mm} \text { (undried) } \\
\text { (EN15804 A1-A3) }\end{array}$ & $\mathrm{DE}$ & " \\
\hline Container ship & - & - & $\begin{array}{l}\text { Container ship, } 5000 \text { to } \\
\text { 200,000 dwt payload } \\
\text { capacity, ocean going }\end{array}$ & GLO & “ \\
\hline Diesel & $\begin{array}{l}\text { Diesel } 7 \% \\
\text { bioblend }\end{array}$ & Diesel $6,4 \%$ bioblend & $\begin{array}{l}\text { Diesel mix at } \\
\text { filling station }\end{array}$ & EU-28 & " \\
\hline Diesel combustion & $\begin{array}{c}\text { Diesel } \\
\text { combustion }\end{array}$ & $\begin{array}{l}\text { Combustion of diesel (modified } \\
\text { for diesel } 7 \% \text { bioblend) }\end{array}$ & $\begin{array}{l}\text { Diesel combustion } \\
\text { in construction } \\
\text { machine }\end{array}$ & GLO & “ \\
\hline Electricity & $\begin{array}{l}\text { Swedish grid } \\
\text { mix electricity }\end{array}$ & - & Electricity grid mix & SE & " \\
\hline $\begin{array}{c}\text { Electricity } \\
\text { generation from } \\
\text { waste incineration }\end{array}$ & $\begin{array}{c}\text { Electricity } \\
\text { generation from } \\
\text { incineration } \\
\text { wood, particle } \\
\text { board, plywood, } \\
\text { plastic, bitumen } \\
\text { sheet, and } \\
\text { hazardous waste }\end{array}$ & Swedish grid mix electricity & Electricity grid mix & SE & " \\
\hline Epoxy sealant & $\begin{array}{l}\text { NM Försegling } \\
\text { 62F Tix }\end{array}$ & Primer for exterior applications & $\begin{array}{c}\text { Powder coating based } \\
\text { on epoxy resin } \\
(\text { EN15804 A1-A3) }\end{array}$ & $\mathrm{DE}$ & “ \\
\hline Form oil & Form oil & From crude oil & Lubricants at refinery & EU-28 & $"$ \\
\hline
\end{tabular}


Table A1. Cont.

\begin{tabular}{|c|c|c|c|c|c|}
\hline Inventory & Description & Assumption & GaBi Dataset & Country & Source \\
\hline Geotextile & $\begin{array}{c}\text { Drefon ST 550 } \\
\text { (polypropylene } \\
\text { fibre geotextile) }\end{array}$ & $\begin{array}{l}\text { Approximated } \\
\text { by woven cotton } \\
\text { fibre fabric }\end{array}$ & $\begin{array}{l}\text { Textile Manufacturing } \\
\text { —Woven Fabric }\end{array}$ & GLO & $\begin{array}{l}\text { Generic dataset } \\
\text { from CottonInc }\end{array}$ \\
\hline Graffiti protection & $\begin{array}{l}\text { Graffiti Shield } \\
\text { wax emulsion }\end{array}$ & From crude oil & $\begin{array}{l}\text { Wax/Paraffins at } \\
\text { refinery }\end{array}$ & $\mathrm{DE}$ & $\begin{array}{l}\text { Generic dataset } \\
\text { from Sphera }\end{array}$ \\
\hline $\begin{array}{l}\text { Hazardous waste } \\
\text { treatment }\end{array}$ & - & Incineration & $\begin{array}{l}\text { Hazardous waste } \\
\text { in waste } \\
\text { incineration plant }\end{array}$ & SE & “ \\
\hline HDG steel racks & $\begin{array}{c}\text { Birsta } W \text {, single } \\
\text { sided safety barrier } \\
\text { (HDG) }\end{array}$ & $\begin{array}{l}\text { Produced by blast } \\
\text { furnace (BF) route, } \\
\text { average European } \\
\text { production }\end{array}$ & $\begin{array}{c}\text { Steel forged } \\
\text { component } \\
\text { (EN15804 A1-A3) }\end{array}$ & EU-28 & " \\
\hline HDG steel recycling & - & $\begin{array}{l}\text { Average German } \\
\text { production }\end{array}$ & $\begin{array}{l}\text { Recycling potential } \\
\text { steel sheet } \\
\text { galvanised } \\
\text { (EN15804 D) }\end{array}$ & $\mathrm{DE}$ & " \\
\hline $\begin{array}{l}\text { HDG structural } \\
\text { steel plates }\end{array}$ & $\begin{array}{l}\text { SSAB Hot-rolled } \\
\text { coils S355MC, } \\
\text { produced in a blast } \\
\text { furnace (BF) route } \\
\text { in Sweden and } \\
\text { galvanized } \\
\text { in Poland }\end{array}$ & $\begin{array}{l}\text { Produced through } \\
\text { a BF route and } \\
\text { galvanized, } \\
\text { German average }\end{array}$ & $\begin{array}{l}\text { Steel sheet HDG } \\
\text { (EN } 15804 \text { A1-A3) }\end{array}$ & $\mathrm{DE}$ & “ \\
\hline HVO combustion & HVO combustion & $\begin{array}{l}\text { Approximated by } \\
\text { a combination of } \\
\text { biomass/regular } \\
\text { diesel combustion }\end{array}$ & $\begin{array}{l}\text { HVO combustion } \\
\text { in car }\end{array}$ & GLO & $\begin{array}{l}\text { Dataset based on } \\
\text { CO2e emission } \\
\text { data from the } \\
\text { Swedish EPA 2018, } \\
\text { combustion of } \\
\text { "Other biomass", } \\
\text { other emissions } \\
\text { (SO2, NOx, PM } \\
\text { etc.) based on data } \\
\text { for regular diesel }\end{array}$ \\
\hline $\begin{array}{c}\text { Hydrogenated } \\
\text { Vegetable Oil (HVO) }\end{array}$ & HVO combustion & $\begin{array}{l}\text { Approximated } \\
\text { by RME }\end{array}$ & $\begin{array}{l}\text { Rapeseed Methyl } \\
\text { Ester (RME) }\end{array}$ & $\mathrm{DE}$ & " \\
\hline $\begin{array}{c}\text { Impregnation } \\
\text { (direct emissions) }\end{array}$ & SILRES ${ }^{\circledR}$ BS 1701 & $\begin{array}{c}\text { Silicate } \\
\text { emulsion primer }\end{array}$ & $\begin{array}{l}\text { Primer silicate } \\
\text { emulsion (building, } \\
\text { exterior, white) } \\
\text { (EN15804 A5) }\end{array}$ & $\mathrm{DE}$ & " \\
\hline $\begin{array}{l}\text { Impregnation } \\
\text { (production) }\end{array}$ & SILRES $^{\circledR}$ BS 1701 & $\begin{array}{l}\text { Silicate emulsion } \\
\text { prime coat }\end{array}$ & $\begin{array}{l}\text { Primer silicate } \\
\text { emulsion (building, } \\
\text { exterior, white) } \\
\text { (EN15804 A1-A3) }\end{array}$ & $\mathrm{DE}$ & “ \\
\hline $\begin{array}{l}\text { Liquified Petroleum } \\
\text { Gas (LPG) }\end{array}$ & $\begin{array}{c}\text { Liquified } \\
\text { Petroleum Gas }\end{array}$ & $\begin{array}{l}\text { average European } \\
\text { production }\end{array}$ & $\begin{array}{l}\text { Thermal energy } \\
\text { from LPG }\end{array}$ & EU-28 & “ \\
\hline Macadam 8/16 mm & $\begin{array}{l}\text { Crushed macadam } \\
8 / 16 \text { from igneous } \\
\text { rock in Sweden }\end{array}$ & $\begin{array}{c}\text { European } \\
\text { limestone } 16 / 32 \\
\text { mm crushed rock }\end{array}$ & $\begin{array}{c}\text { Crushed rock 16-32 } \\
\text { mm (undried) } \\
\text { (EN15804 A1-A3) }\end{array}$ & EU-28 & " \\
\hline Mortar & $\begin{array}{c}\text { Fine concrete K40 } \\
\text { and expander } \\
\text { concrete EXM } 702\end{array}$ & $\begin{array}{l}\text { Average European } \\
\text { production }\end{array}$ & $\begin{array}{l}\text { Normal mortar } \\
\quad(A 1-A 3)\end{array}$ & EU-28 & " \\
\hline Particle board & $\begin{array}{l}\text { Form board } \\
\text { from Sweden }\end{array}$ & $\begin{array}{l}\text { Average European } \\
\text { P2 (Standard FPY) }\end{array}$ & Particle board & EU-28 & “ \\
\hline Plastic film & - & - & $\begin{array}{c}\text { Plastic Film (PE, PP, } \\
\text { PVC) }\end{array}$ & GLO & " \\
\hline Plastic waste treatment & $\begin{array}{l}\text { Incineration in } \\
\text { Swedish district } \\
\text { heating plant } \\
\text { (Jönköping) }\end{array}$ & $\begin{array}{c}\text { Incineration } \\
\text { in average } \\
\text { European waste } \\
\text { incineration plant }\end{array}$ & $\begin{array}{l}\text { Plastic packaging } \\
\text { in municipal waste } \\
\text { incineration plant }\end{array}$ & EU-28 & “ \\
\hline Plywood & $\begin{array}{l}\text { Formply from } \\
\text { Sweden }\end{array}$ & $\begin{array}{l}\text { Pine plywood } \\
\text { produced } \\
\text { in Germany }\end{array}$ & $\begin{array}{l}\text { Plywood board } \\
\text { (EN15804 A1-A3) }\end{array}$ & $\mathrm{DE}$ & “ \\
\hline $\begin{array}{l}\text { Plywood and } \\
\text { particleboard } \\
\text { waste treatment }\end{array}$ & $\begin{array}{l}\text { Incineration } \\
\text { in Swedish district } \\
\text { heating plant } \\
\text { (Jönköping) }\end{array}$ & $\begin{array}{l}\text { Incineration } \\
\text { in German waste } \\
\text { incineration plant }\end{array}$ & $\begin{array}{c}\text { Particle board } \\
\text { in municipal waste } \\
\text { incineration plant }\end{array}$ & $\mathrm{DE}$ & “ \\
\hline Polyethylene foam & Concrete carpet & $\begin{array}{c}\text { Consisting of } \\
\text { polyethylene foam }\end{array}$ & $\begin{array}{l}\text { Polyethylene foam } \\
\text { (EN15804 A1-A3) }\end{array}$ & $\mathrm{DE}$ & “ \\
\hline Polypropylene pipe & PP road drum & $\begin{array}{l}\text { PP pipe produced } \\
\text { in Germany }\end{array}$ & $\begin{array}{c}\text { Polypropylene } \\
\text { pipe (PP) (EN15804 } \\
\text { A1-A3) }\end{array}$ & $\mathrm{DE}$ & " \\
\hline
\end{tabular}


Table A1. Cont.

\begin{tabular}{|c|c|c|c|c|c|}
\hline Inventory & Description & Assumption & GaBi Dataset & Country & Source \\
\hline PVC tube & PVC drain hose & $\begin{array}{l}\text { PVC drain pipe } \\
\text { produced } \\
\text { in Germany }\end{array}$ & $\begin{array}{c}\text { Rain drain pipe (PVC } \\
\text { pipe) (EN15804 } \\
\text { A1-A3) }\end{array}$ & $\mathrm{DE}$ & “ \\
\hline $\begin{array}{l}\text { PVC waste } \\
\text { treatment }\end{array}$ & $\begin{array}{l}\text { PVC waste } \\
\text { incineration } \\
\text { in Swedish district } \\
\text { heating plant } \\
\text { (Jönköping) }\end{array}$ & $\begin{array}{c}\text { Incineration } \\
\text { in German waste } \\
\text { incineration plant }\end{array}$ & $\begin{array}{l}\text { Polyvinyl chloride } \\
\text { (PVC) in waste } \\
\text { incineration plant }\end{array}$ & $\mathrm{DE}$ & $"$ \\
\hline $\begin{array}{c}\text { Ready-mix } \\
\text { concrete C35/45 }\end{array}$ & $\begin{array}{c}\text { Betongindustri } \\
\text { concrete C } 35 / 45 \\
\text { vct }=0,40\end{array}$ & $\begin{array}{l}\text { Average European } \\
\text { production }\end{array}$ & $\begin{array}{c}\text { Concrete C35/45 } \\
\text { (Ready-mix concrete) } \\
(\text { EN15804 A1-A3) }\end{array}$ & EU-28 & $"$ \\
\hline $\begin{array}{l}\text { Recovery of heat } \\
\text { for district heating }\end{array}$ & $\begin{array}{l}\text { Heat recovery from } \\
\text { wood, particle } \\
\text { board, plywood, } \\
\text { plastic, bitumen } \\
\text { sheet, and } \\
\text { hazardous waste }\end{array}$ & $\begin{array}{l}\text { District heating } \\
\text { produced by plant } \\
\text { in Jönköping }\end{array}$ & $\begin{array}{l}\text { District heating mix } \\
\text { Jönköping } 2019\end{array}$ & SE & $\begin{array}{c}\text { Specific dataset } \\
\text { based on fuel } \\
\text { use for } \\
\text { Jönköping } \\
\text { district heating } \\
\text { plant }\end{array}$ \\
\hline $\begin{array}{l}\text { Reinforcement } \\
\text { (carbon steel) }\end{array}$ & B500B & $\begin{array}{c}\text { Produced by } \\
\text { the electric arc } \\
\text { furnace (EAF) route, } \\
\text { average European } \\
\text { production }\end{array}$ & $\begin{array}{l}\text { Reinforced steel (wire) } \\
\text { (EN15804 A1-A3) }\end{array}$ & EU-28 & $\begin{array}{l}\text { Generic dataset } \\
\text { from Sphera }\end{array}$ \\
\hline $\begin{array}{l}\text { Reinforcement } \\
\text { (stainless steel) }\end{array}$ & LDX2101 & $\begin{array}{l}\text { Produced from } 100 \% \\
\text { alloyed stainless } \\
\text { steel scrap }\end{array}$ & $\begin{array}{c}\text { Fixing material screws } \\
\text { stainless steel } \\
(\text { EN15804 A1-A3) }\end{array}$ & $\mathrm{DE}$ & “ \\
\hline Road salt & - & From rock salt & $\begin{array}{l}\text { Sodium chloride (rock } \\
\text { salt) }\end{array}$ & $\mathrm{DE}$ & " \\
\hline Untreated wood & $\begin{array}{l}\text { Spruce wood } \\
\text { from Sweden }\end{array}$ & $\begin{array}{l}\text { Coniferous wood } \\
\text { produced } \\
\text { in Germany }\end{array}$ & $\begin{array}{l}\text { Solid construction } \\
\text { timber (softwood) } \\
\text { (EN15804 A1-A3) }\end{array}$ & $\mathrm{DE}$ & $"$ \\
\hline $\begin{array}{l}\text { Wood waste } \\
\text { treatment }\end{array}$ & $\begin{array}{l}\text { Wood waste } \\
\text { incineration in } \\
\text { Swedish district } \\
\text { heating plant } \\
\text { (Jönköping) }\end{array}$ & $\begin{array}{c}\text { Incineration } \\
\text { in German waste } \\
\text { incineration plant }\end{array}$ & $\begin{array}{l}\text { Wood (natural) in } \\
\text { waste incineration } \\
\text { plant }\end{array}$ & $\mathrm{DE}$ & “ \\
\hline
\end{tabular}

" denotes 'Same as above'.

\section{Appendix B}

Table A2. Bill of materials (BOM) for the design concepts for each module. Amounts are representative of the required service life (RSL) and for the bridges as a whole. The amounts for modules B1-B8, C1-C4 and D were calculated based on the scenarios presented in Tables A3-A5.

\begin{tabular}{|c|c|c|c|c|}
\hline Concept & Module & Resource/Waste & Amount & Unit \\
\hline & \multirow{6}{*}{ A1-A3 } & Aggregates $0 / 16$ and $0 / 90 \mathrm{~mm}$ & $6,820,600$ & $\mathrm{~kg}$ \\
\hline & & Macadam 8/16 mm & 12,000 & $\mathrm{~kg}$ \\
\hline & & Asphalt Abb & 6983 & $\mathrm{~kg}$ \\
\hline & & Asphalt ABT & 4364 & $\mathrm{~kg}$ \\
\hline & & Asphalt ViacoGrip & 5237 & $\mathrm{~kg}$ \\
\hline & & Concrete elements & 8100 & $\mathrm{~kg}$ \\
\hline
\end{tabular}


Table A2. Cont.

\begin{tabular}{|c|c|c|c|c|}
\hline Concept & Module & Resource/Waste & Amount & Unit \\
\hline \multirow{33}{*}{ Both } & & Hot-dip galvanized (HDG) steel racks & 250 & $\mathrm{~kg}$ \\
\hline & & Polypropylene pipe & 106 & $\mathrm{~kg}$ \\
\hline & & Geotextile & 17 & $\mathrm{~kg}$ \\
\hline & \multirow{4}{*}{ A5 } & Electricity (Swedish grid mix) & 4560 & $\mathrm{kWh}$ \\
\hline & & Tap water & 1500 & liters \\
\hline & & PVC tube & 105 & $\mathrm{~kg}$ \\
\hline & & PVC waste & 105 & $\mathrm{~kg}$ \\
\hline & \multirow[b]{2}{*}{ B1 } & Zinc to fresh water & 0.55 & $\mathrm{~kg}$ \\
\hline & & PAH to fresh water & 0.112 & $\mathrm{~kg}$ \\
\hline & \multirow{2}{*}{ B2 } & Tap water & 400 & liters \\
\hline & & Road salt & 65 & $\mathrm{~kg}$ \\
\hline & \multirow{2}{*}{ B3 } & HDG steel racks & 692 & $\mathrm{~kg}$ \\
\hline & & HDG steel racks waste for recycling & 692 & $\mathrm{~kg}$ \\
\hline & \multirow{5}{*}{ B4 } & HDG steel racks & 692 & $\mathrm{~kg}$ \\
\hline & & Asphalt & 10,500 & $\mathrm{~kg}$ \\
\hline & & Diesel 7\% bioblend & 17 & liters \\
\hline & & Tap water & 10,000 & liters \\
\hline & & HDG steel racks waste for recycling & 692 & $\mathrm{~kg}$ \\
\hline & B5 & N/A & - & \\
\hline & B6 & N/A & - & \\
\hline & B7 & N/A & - & \\
\hline & \multirow{5}{*}{ B8 } & Diesel 7\% bioblend & 11,797 & liters \\
\hline & & Hydrogenated Vegetable Oil (HVO) & 41,611 & liters \\
\hline & & Electricity (Swedish grid mix) & 357,209 & $\mathrm{kWh}$ \\
\hline & & Particles to fresh water & 10,950 & $\mathrm{~kg}$ \\
\hline & & Micro plastics to soil & 131 & $\mathrm{~kg}$ \\
\hline & $\mathrm{C} 1$ & Diesel 7\% bioblend & 39 & liters \\
\hline & $\mathrm{C} 2$ & See Table A6 & - & \\
\hline & \multirow{3}{*}{$\mathrm{C} 3$} & Aggregates for re-use & $6,149,340$ & $\mathrm{Kg}$ \\
\hline & & Asphalt waste for recycling & 16,580 & $\mathrm{Kg}$ \\
\hline & & Polypropylene plastic waste for incineration & 106 & $\mathrm{Kg}$ \\
\hline & $\mathrm{C} 4$ & Aggregates on inert landfill & 683,260 & $\mathrm{Kg}$ \\
\hline & $\mathrm{D}$ & Electricity (Swedish grid mix) & 19 & $\mathrm{kWh}$ \\
\hline \multirow{20}{*}{ CSF bridge } & \multirow{11}{*}{$\mathrm{A} 1-\mathrm{A} 3$} & Ready-mix concrete C35/45 & 463,700 & $\mathrm{Kg}$ \\
\hline & & Reinforcement (carbon steel) & 22,680 & $\mathrm{Kg}$ \\
\hline & & Reinforcement (stainless steel) & 553 & $\mathrm{~kg}$ \\
\hline & & Bitumen sheet & 380 & $\mathrm{~kg}$ \\
\hline & & Mortar & 180 & $\mathrm{~kg}$ \\
\hline & & Epoxy sealant & 77 & $\mathrm{~kg}$ \\
\hline & & Bituprimer & 35 & $\mathrm{~kg}$ \\
\hline & & Impregnation & 19 & liters \\
\hline & & Graffiti protection & 19 & liters \\
\hline & & Bitumen sealant & 10 & $\mathrm{~kg}$ \\
\hline & & Polyethylene foam & 5 & $\mathrm{~kg}$ \\
\hline & \multirow{9}{*}{ A5 } & Untreated wood & 5400 & $\mathrm{~kg}$ \\
\hline & & Diesel 7\% bioblend & 5280 & liters \\
\hline & & Particle board & 1600 & $\mathrm{~kg}$ \\
\hline & & Plywood & 1000 & $\mathrm{~kg}$ \\
\hline & & Form oil & 130 & $\mathrm{~kg}$ \\
\hline & & Plastic film & 22 & $\mathrm{~kg}$ \\
\hline & & Concrete waste for recycling & 23,185 & $\mathrm{~kg}$ \\
\hline & & Wood waste for incineration & 5400 & $\mathrm{~kg}$ \\
\hline & & Plywood and particleboard waste for incineration & 2600 & $\mathrm{~kg}$ \\
\hline
\end{tabular}


Table A2. Cont.

\begin{tabular}{|c|c|c|c|c|}
\hline Concept & Module & Resource/Waste & Amount & Unit \\
\hline & & Reinforcement waste (carbon steel) for recycling & 1134 & $\mathrm{~kg}$ \\
\hline & & Plastic waste for incineration & 22 & $\mathrm{~kg}$ \\
\hline & & Bitumen sheet waste for incineration & 19 & $\mathrm{~kg}$ \\
\hline & \multirow{2}{*}{ B1 } & $\mathrm{CO}_{2}$ uptake & 1139 & $\mathrm{~kg}$ \\
\hline & & Zinc oxide to air & 0.55 & $\mathrm{~kg}$ \\
\hline & \multirow{3}{*}{ B2 } & Diesel 7\% bioblend & 70 & liters \\
\hline & & Tap water & 29,400 & liters \\
\hline & & Graffiti shield & 15 & liters \\
\hline & \multirow{3}{*}{ B3 } & Concrete C35/45 & 1344 & $\mathrm{~kg}$ \\
\hline & & Tap water & 1000 & liters \\
\hline & & Concrete waste & 1411 & $\mathrm{~kg}$ \\
\hline & \multirow{10}{*}{ B4 } & Concrete C35/45 & 12,600 & $\mathrm{~kg}$ \\
\hline & & Diesel 7\% bioblend & 27 & liters \\
\hline & & Bitumen sealant & 10 & $\mathrm{~kg}$ \\
\hline & & Bitumen sheet & 380 & $\mathrm{~kg}$ \\
\hline & & Bituprimer & 35 & $\mathrm{~kg}$ \\
\hline & & Epoxy sealant & 77 & $\mathrm{~kg}$ \\
\hline & & Bitumen sealant waste for incineration & 10 & $\mathrm{~kg}$ \\
\hline & & Bitumen sheet waste for incineration & 380 & $\mathrm{~kg}$ \\
\hline & & Bituprimer waste for incineration & 35 & $\mathrm{~kg}$ \\
\hline & & Epoxy sealant waste for incineration & 77 & $\mathrm{~kg}$ \\
\hline & \multirow{2}{*}{$\mathrm{C} 1$} & Diesel 7\% bioblend & 1453 & liters \\
\hline & & Tap water & 386,000 & liters \\
\hline & $\mathrm{C} 2$ & See Table A6 & - & \\
\hline & \multirow{8}{*}{$\mathrm{C} 3$} & Concrete for recycling & 448,615 & $\mathrm{~kg}$ \\
\hline & & HDG steel for recycling & 250 & $\mathrm{~kg}$ \\
\hline & & Carbon steel reinforcement for recycling & 22,680 & $\mathrm{~kg}$ \\
\hline & & Stainless steel reinforcement for recycling & 553 & $\mathrm{~kg}$ \\
\hline & & Bitumen sealant waste for incineration & 10 & $\mathrm{~kg}$ \\
\hline & & Bitumen sheet waste for incineration & 380 & $\mathrm{~kg}$ \\
\hline & & Bituprimer waste for incineration & 35 & $\mathrm{~kg}$ \\
\hline & & Epoxy sealant waste for incineration & 77 & $\mathrm{~kg}$ \\
\hline & $\mathrm{C} 4$ & N/A & - & \\
\hline & $\mathrm{D}$ & Electricity (Swedish grid mix) & 340 & $\mathrm{kWh}$ \\
\hline \multirow{13}{*}{ SSC bridge } & A1-A3 & HDG structural steel plates incl. bolts and nuts & 40,653 & $\mathrm{~kg}$ \\
\hline & A5 & Diesel 7\% bioblend & 5230 & liters \\
\hline & B1 & Zinc oxide to air & 3.35 & $\mathrm{~kg}$ \\
\hline & & Diesel 7\% bioblend & 52 & liters \\
\hline & B2 & Tap water & 26,200 & liters \\
\hline & B3 & N/A & - & \\
\hline & B4 & N/A & - & \\
\hline & $C 1$ & Acetylene & 8300 & liters \\
\hline & C1 & Diesel 7\% bioblend & 2339 & liters \\
\hline & $\mathrm{C} 2$ & See Table A6 & - & \\
\hline & $\mathrm{C} 3$ & $\begin{array}{l}\text { HDG structural steel plates incl. bolt and nuts for } \\
\text { recycling }\end{array}$ & 40,653 & $\mathrm{~kg}$ \\
\hline & $\mathrm{C} 4$ & $\mathrm{~N} / \mathrm{A}$ & - & \\
\hline & $\mathrm{D}$ & $\mathrm{N} / \mathrm{A}$ & - & \\
\hline
\end{tabular}




\section{Appendix C}

Common scenarios for both design concepts are presented in Table A3. Specific scenarios for the CSF bridge and the SSC bridge design concepts are presented in Tables A4 and A5, respectively.

Table A3. Common scenarios for both design concepts for each module (B-D).

\begin{tabular}{ll}
\hline Module & \multicolumn{1}{c}{ Scenario } \\
\hline & (1) $\quad \begin{array}{l}\text { Zinc in steel racks oxidizes and is released to air and water. The amount of zinc } \\
\text { released from galvanized steel racks on a highway was calculated to be } 0.95 \\
\mathrm{~kg} / \mathrm{y} \text { ear } / \mathrm{km} \text { [34]. It is assumed that } 50 \% \text { of this is released as zinc oxide particles to air } \\
\text { and } 50 \% \text { is released in soluble form to water, giving a total of } 0.55 \mathrm{~kg} \text { of zinc released } \\
\text { from the bridge to water and air respectively over } 80 \text { years. }\end{array}$ \\
Bitumen in asphalt is degraded and PAH leaches into the local environment at a rate \\
(2) $0.5 \mathrm{mg}$ PAH $/ \mathrm{m}^{2}$ asphalt over 25 years [35], giving a total of $112 \mathrm{mg}$ of PAH is \\
released from the bridge to soil over 80 years.
\end{tabular}

(1) Washing of steel racks with drinking water occurs twice a year. Approximately $25 \mathrm{~L}$ is used per $100 \mathrm{~m}$ rack according to expertise within the Swedish Transport Administration, giving $400 \mathrm{~L}$ of water consumed over 80 years. The work cost is negligible and therefore was not included.

B2

(2) A total of $0.8 \mathrm{~kg}$ of salt is administered per year across the whole road surface of the bridge [36], giving $65 \mathrm{~kg}$ over 80 years. The work cost is negligible and therefore was not included.

(3) A total of $0.07 \mathrm{~h}$ is needed for snow removal per $\mathrm{km}$ of lane per year [36]. The bridge has 3 lanes, and we assumed the use of a diesel-driven vehicle of $100 \mathrm{~kW}$, giving $1.3 \mathrm{~L}$ of diesel over 80 years, which is considered negligible and was therefore not included.

$10 \%$ of the steel rack mass is repaired every second year, giving $692 \mathrm{~kg}$ over 80 years. The cost for this amount of steel is 8650 Euros. The energy used for the repairs is estimated to be negligible and was therefore not included. The work cost was calculated assuming $1 \mathrm{~h}$ of work per occasion and a salary of 60 Euros/h, giving 2400 Euros.

(1) Steel racks are replaced completely every 20 years, giving $692 \mathrm{~kg}$ over 80 years. The cost for this amount of steel is 8650 Euro of which the work cost is 2400 Euro.

(2) A depth of $30 \mathrm{~mm}$ of the top asphalt layer is replaced every 40 years, giving $10,500 \mathrm{~kg}$ of asphalt over 80 years. The amount of diesel used for milling is $1.6 \mathrm{~L} /$ ton asphalt milled, giving $17 \mathrm{~L}$ over 80 years. The work cost is negligible and was therefore not included.

\begin{tabular}{ll}
\hline B5 & No refurbishment needed \\
\hline B6 & No energy consumption \\
\hline B7 & No water consumption \\
\hline
\end{tabular}

(1) Energy consumption of passing vehicles: It is estimated that the mean daily traffic on the bridge per year over the RSL will increase, as illustrated in Figure A1. It is assumed that $50 \%$ of the vehicles will be diesel-driven and $50 \%$ will be electric up until 2030; $20 \%$ will be diesel-driven, $20 \%$ will be HVO-driven, and $60 \%$ will be electric in 2030-2045; and 30\% will be HVO-driven and 70\% electric from 2045 onwards. The diesel and HVO consumption is assumed to $0,06 \mathrm{~L} / \mathrm{km}$ and B8 the electricity consumption is assumed to be $0.2 \mathrm{kWh} / \mathrm{km}$, giving $11,797 \mathrm{~L}$ of diesel, $41,611 \mathrm{~L}$ of $\mathrm{HVO}$, and $357,209 \mathrm{kWh}$ of electricity over 80 years.

(2) A total of $760 \mathrm{~kg}$ of asphalt is abraded per $100 \mathrm{~m}$ lane/year (at AADT 15,000, $100 \mathrm{~km} / \mathrm{h}$ according to [37], giving 10,950 kg particles (of diameter 50-1000 $\mu \mathrm{m}$ ) over 80 years.

(3) Tires are abraded by $0.05 \mathrm{~g} / \mathrm{km}$ and vehicles [38], giving $131 \mathrm{~kg}$ of microplastic over 80 years ( $25 \%$ styrene and $75 \%$ butadiene).

(1) Steel racks are lifted away using a diesel-driven crane. It is estimated that $1 \mathrm{~h}$ is needed for $14 \mathrm{~m}$ of racks using a crane that consumes $12 \mathrm{~L} / \mathrm{h}$ [39], giving $12 \mathrm{~L}$ of diesel. The work cost is negligible and was therefore not included.

(2) Asphalt is milled using a machine that consumes $1.6 \mathrm{~L}$ of diesel/ton asphalt milled, giving $27 \mathrm{~L}$. The work cost was calculated assuming $16 \mathrm{~h}$ of work and a salary of 60 Euros/h, giving 1000 Euro. 
Table A3. Cont.

\begin{tabular}{|c|c|}
\hline Module & Scenario \\
\hline $\mathrm{C} 2$ & $\begin{array}{l}\text { (1) Steel racks are transported by truck to a storage facility. } \\
\text { (2) Asphalt is transported by truck to recycling. } \\
\text { (3) A total of } 90 \% \text { of the aggregates are not moved, and } 10 \% \text { are transported } 39 \mathrm{~km} \text { by } \\
\text { truck to landfill. }\end{array}$ \\
\hline $\mathrm{C} 3$ & $\mathrm{~N} / \mathrm{A}$, end-of-waste is reached for asphalt and steel racks before waste treatment takes place. \\
\hline $\mathrm{C} 4$ & $\begin{array}{l}\text { A total of } 10 \% \text { of the aggregates are disposed on an inert landfill }=683,260 \mathrm{~kg} \text {. The cost for } \\
\text { landfilling is } 30 \text { Euros/ton. }\end{array}$ \\
\hline $\mathrm{D}$ & $\begin{array}{l}\text { (1) } 100 \% \text { of the steel racks are recycled. The selling price is } 0.1 \mathrm{Euro} / \mathrm{kg} \text { steel. } \\
\text { (2) } 100 \% \text { of the asphalt is recycled. Crushing of the recycled asphalt is done with } \\
\text { an electric crusher using } 0.7 \mathrm{kWh} / \text { ton, giving } 19 \mathrm{kWh} \text { in total. The selling price is } 5 \\
\text { Euros/ton asphalt. } \\
\text { (3) A total of } 90 \% \text { of the aggregates are not moved and are re-used as filling material } \\
\text { on site. }\end{array}$ \\
\hline
\end{tabular}

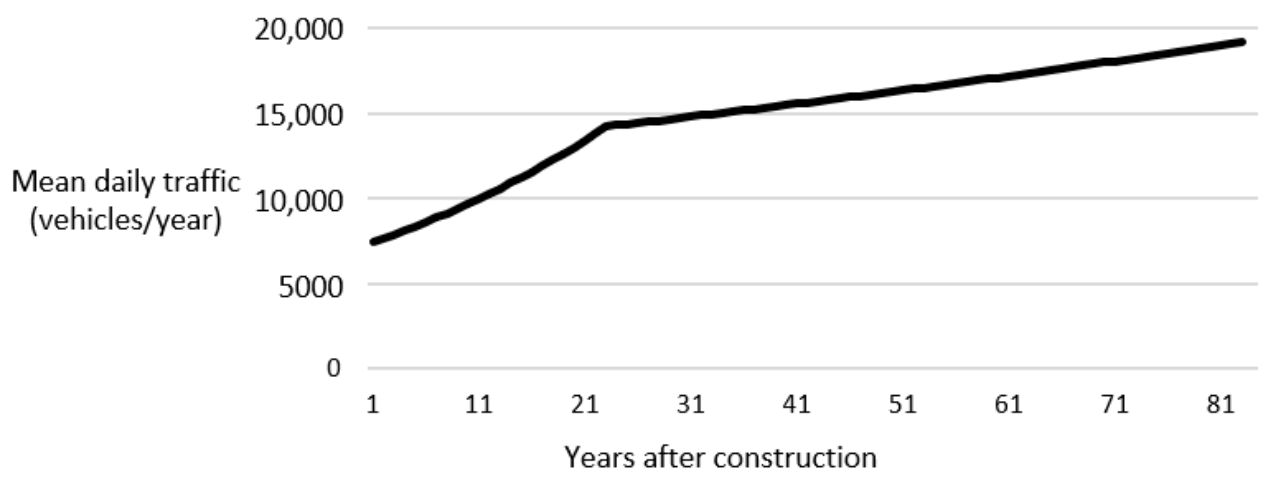

Figure A1. Estimated mean daily traffic on the bridge per year over the RSL (up to 80 years after construction).

Table A4. Specific scenarios for the CSF bridge design concept for each module (B-D).

\begin{tabular}{ll}
\hline Module & \multicolumn{1}{c}{ Scenario } \\
\hline & Carbonation of the concrete surfaces was calculated according to [40] with the \\
following assumptions: \\
- $\quad$ Area exposed to rain: $55 \mathrm{~m}^{2}$ \\
- $\quad$ Area protected from rain: $210 \mathrm{~m}^{2}$ \\
giving that $1139 \mathrm{~kg} \mathrm{CO}_{2}$ is taken up by the bridge over 80 years. \\
Graffiti removal is done every 10 years by washing with hot water under high pressure. \\
After washing, new graffiti protection is applied. It is assumed that $10 \%$ of the \\
available surface area of $170 \mathrm{~m} \mathrm{~m}^{2}$ is covered by graffiti over 10 years, giving $17 \mathrm{~m}{ }^{2}$. It is \\
estimated that it takes $15 \mathrm{~min}$ to wash $1 \mathrm{~m}{ }^{2}$, giving $4 \mathrm{~h}$ to wash in total per occasion. \\
The equipment consumes $2.15 \mathrm{~L}$ of diesel/h, giving $70 \mathrm{~L}$ over 80 years. It consumes $15 \mathrm{~L}$ \\
of drinking water/minute, giving $29.4 \mathrm{~m}{ }^{3}$ in total over 80 years. Graffiti protection \\
of $10 \%$ of the surface, giving $15 \mathrm{~L}$ over 80 years. \\
The work cost was calculated assuming $32 \mathrm{~h}$ of work and a salary of 60 Euros/h, giving \\
1920 Euro.
\end{tabular}


Table A4. Cont.

\begin{tabular}{|c|c|}
\hline Module & Scenario \\
\hline B3 & $\begin{array}{l}\text { Minor repairs in the concrete parts are needed every } 10 \text { years. A } 1 \mathrm{~m}^{2} \text { layer of concrete } \\
\text { with a thickness of } 70 \mathrm{~mm} \text { is repaired per occasion, giving } 1344 \mathrm{~kg} \text { concrete repaired } \\
\text { over } 80 \text { years. A total of } 2000 \mathrm{~L} \text { of water is used per } \mathrm{m}^{3} \text { of concrete repaired, giving } \\
1000 \mathrm{~L} \text { over } 80 \text { years. The amount of diesel consumed is negligible and was therefore } \\
\text { not included. } \\
\text { The work cost was calculated assuming } 14 \mathrm{~h} \text { of work and a salary of } 60 \text { Euros/h, giving } \\
840 \text { Euros. }\end{array}$ \\
\hline B4 & $\begin{array}{l}\text { Replacement of edge beams is done every } 40 \text { years. The two edge beams are } 400 \mathrm{~mm} \\
\text { wide, } 500 \mathrm{~mm} \text { high, and } 6 \mathrm{~m} \text { long, giving } 5 \mathrm{~m}^{3} \text { of concrete is replaced over } 80 \text { years. } \\
\text { The equipment has a diesel consumption of } 5.3 \mathrm{~L} / \mathrm{h} \text {, and } 1 \mathrm{~m}^{3} \text { concrete is removed/h, } \\
\text { giving } 27 \mathrm{~L} \text { over } 80 \text { years. It also consumes } 2000 \mathrm{~L} \text { of drinking water/h [41], giving } 10 \\
\mathrm{~m}^{3} \text { in total over } 80 \text { years. The bridge insulation is totally replaced every } 40 \text { years, } \\
\text { giving } 77 \mathrm{~kg} \text { of epoxy sealant, } 10 \mathrm{~kg} \text { of bitumen sealant, } 35 \mathrm{~kg} \text { of bituprimer, and } 380 \mathrm{~kg} \\
\text { of bitumen sheet over } 80 \text { years. } \\
\text { The work cost was calculated assuming } 16 \mathrm{~h} \text { of work and a salary of } 60 \text { Euros/h, giving } \\
1000 \text { Euro. The cost for } 1 \text { day of scaffolding rent is estimated to be } 100 \text { Euros. }\end{array}$ \\
\hline
\end{tabular}

(1) Concrete is demolished using equipment that consumes $2000 \mathrm{~L}$ of drinking water and $5.3 \mathrm{~L}$ of diesel per $\mathrm{m}^{3}$ of concrete, giving $386 \mathrm{~m}^{3}$ water and $1023 \mathrm{~L}$ of diesel in total. The work cost was calculated assuming $193 \mathrm{~h}$ of work and a salary of 60 Euros/h, giving 11,600 Euros.

C1 (2) A total of $90 \%$ of the aggregates is not handled at all, and $10 \%$ is excavated using an excavator consuming $1.5 \mathrm{~L} / \mathrm{m}^{3}$ of excavated material, giving $430 \mathrm{~L}$ of diesel. The work cost was calculated assuming $290 \mathrm{~h}$ of work and a cost of $100 \mathrm{Euros} / \mathrm{h}$, giving 29,000 Euros.

(1) Reinforcement steel is transported by truck to a storage facility.

(2) Concrete is transported by truck to a recycling facility.

\begin{tabular}{cl}
\hline C3 & $\begin{array}{l}\text { N/A, end-of-waste is reached for concrete and reinforcement steel before waste } \\
\text { treatment takes place. }\end{array}$ \\
\hline C4 & N/A, no waste is disposed. \\
\hline
\end{tabular}

(1) All of the concrete is recycled into filling material. Crushing of the recycled concrete is done with an electric crusher using $0.7 \mathrm{kWh} / \mathrm{ton}$, giving $340 \mathrm{kWh}$

$\mathrm{D}$ in total. The selling price is 5.3 Euro/ton concrete.

(2) All of the reinforcement steel is recycled into reinforcement steel. The selling price is 0.1 Euro $/ \mathrm{kg}$ of carbon steel and 0.9 Euro $/ \mathrm{kg}$ of stainless steel.

Table A5. Specific scenarios for the SSC bridge design concept for each module (B-D).

\begin{tabular}{|c|c|}
\hline Module & Scenario \\
\hline B1 & $\begin{array}{l}\text { Zinc oxidizes on the bridge's structural steel plates into a powder which is assumed to } \\
\text { disperse into the surrounding air (since the steel surface is protected from rain). } \\
\text { Conservatively, it is assumed that } 0.5 \mathrm{~g} \text { of } \mathrm{Zn} \text { is dispersed per } \mathrm{m}^{2} \text { plate and year [34,42]. } \\
\text { The area is } 70 \mathrm{~m}^{2} \text {, giving } 2.8 \mathrm{~kg} \text { of } \mathrm{Zn} \text { is released to air over } 80 \text { years. }\end{array}$ \\
\hline B2 & $\begin{array}{l}\text { (1) Graffiti removal is done every } 10 \text { years by washing with hot water under high } \\
\text { pressure. No graffiti protection is needed on steel. It was assumed that } 10 \% \text { of the } \\
\text { available surface area of } 126 \mathrm{~m}^{2} \text { is covered by graffiti over } 10 \text { years, giving } 13 \mathrm{~m}^{2} . \text { It } \\
\text { was estimated that it takes } 15 \mathrm{~min} \text { to wash } 1 \mathrm{~m}^{2} \text {, giving } 3 \mathrm{~h} \text { to wash in total per } \\
\text { occasion. The equipment consumes } 2.15 \mathrm{~L} \text { of diesel/h, giving } 52 \mathrm{~L} \text { over } 80 \text { years. It } \\
\text { consumes } 15 \mathrm{~L} \text { of drinking water/minute, giving } 22.4 \mathrm{~m}^{3} \text { in total over } 80 \text { years. }\end{array}$ \\
\hline
\end{tabular}


Table A5. Cont.

\begin{tabular}{ll}
\hline Module & Scenario \\
& The work cost was calculated assuming $32 \mathrm{~h}$ of work and a salary of 60 Euros/h, giving 1 \\
& 920 Euro. \\
Washing of the bridge's structural steel plates surface of $95 \mathrm{~m}^{2}$ is also done by using hot \\
water under high pressure. It is done once a year using $0.5 \mathrm{~L}$ of drinking water $/ \mathrm{m}^{2}$, giving \\
3800 L over 80 years.
\end{tabular}

\section{Appendix D}

Table A6. Transport modes and distances travelled for the resources (applicable for modules A4, A5, $\mathrm{B} 1-\mathrm{B} 4$ and C2).

\begin{tabular}{|c|c|c|c|}
\hline Concept & Resource & Transport Mode & Distance $(\mathrm{km})$ \\
\hline \multirow{7}{*}{ Both } & $\begin{array}{l}\text { Aggregates (crushed } \\
\text { rock), asphalt }\end{array}$ & $\begin{array}{l}\text { Truck, Euro 6, 20-26 t gross weight/17.3 t } \\
\text { payload capacity, 55\% utilisation }\end{array}$ & 39 \\
\hline & Concrete elements & " & 66 \\
\hline & Diesel 7\% bioblend & " & 100 \\
\hline & Steel racks & “ & 646 \\
\hline & $\begin{array}{l}\text { Aggregate waste, Asphalt } \\
\text { waste, Concrete waste }\end{array}$ & " & 39 \\
\hline & $\begin{array}{l}\text { Steel waste (racks, } \\
\text { reinforcement steel, } \\
\text { stainless steel) }\end{array}$ & " & 50 \\
\hline & Plastic waste & " & 38 \\
\hline \multirow{4}{*}{ CSF bridge } & Ready-mix concrete C35/45 & " & 40 \\
\hline & Reinforcement (carbon steel) & $\begin{array}{c}\text { Average electricity/diesel driven train, } \\
\text { gross tonne weight } 1000 \mathrm{t} / 726 \mathrm{t} \text { payload } \\
\text { capacity, } 40 \% \text { utilisation } \\
\text { Truck Euro 6, 20-26 t gross weight/17.3 t } \\
\text { payload capacity, 55\% utilisation }\end{array}$ & $\begin{array}{c}1510 \\
198\end{array}$ \\
\hline & Reinforcement (stainless steel) & $\begin{array}{c}\text { Container ship, } 5000 \text { to } 200,000 \mathrm{dwt} \\
\text { payload capacity, ocean going, } 70 \% \\
\text { utilisation } \\
\text { Truck Euro 6, 20-26 t gross weight/17.3 t } \\
\text { payload capacity, 55\% utilisation }\end{array}$ & $\begin{array}{c}49 \\
1045\end{array}$ \\
\hline & $\begin{array}{l}\text { Untreated wood, particle } \\
\text { board, plywood }\end{array}$ & $\begin{array}{l}\text { Truck Euro 6, 20-26 t gross weight/17.3 t } \\
\text { payload capacity, 55\% utilisation }\end{array}$ & 20 \\
\hline
\end{tabular}


Table A6. Cont.

\begin{tabular}{|c|c|c|c|}
\hline Concept & Resource & Transport Mode & Distance (km) \\
\hline & $\begin{array}{l}\text { Bitumen sheet waste, } \\
\text { wood waste }\end{array}$ & " & 38 \\
\hline & Hazardous waste & “ & 200 \\
\hline \multirow[t]{2}{*}{ SSC bridge } & Structural steel plates & $\begin{array}{l}\text { Container ship, } 5000 \text { to } 200,000 \mathrm{dwt} \\
\text { payload capacity, ocean going, } \\
70 \% \text { utilisation } \\
\text { Truck Euro } 6,20-26 \mathrm{t} \text { gross weight } / 17.3 \mathrm{t} \\
\text { payload capacity, } 55 \% \text { utilisation }\end{array}$ & $\begin{array}{c}360 \\
2027\end{array}$ \\
\hline & $\begin{array}{l}\text { Steel waste (structural } \\
\text { steel plates) }\end{array}$ & $\begin{array}{l}\text { Truck Euro } 6,20-26 \mathrm{t} \text { gross weight/17.3 } \mathrm{t} \\
\text { payload capacity, } 55 \% \text { utilisation }\end{array}$ & 50 \\
\hline
\end{tabular}

\section{References}

1. ISO. ISO 15392:2019-Sustainability in Buildings and Civil Engineering Works-General Principles, 2nd ed.; International Organization for Standardization (ISO): Geneva, Switzerland, 2019.

2. CEN. EN 15643-5:2017-Sustainability of Construction Works-Sustainability Assessment of Buildings and Civil Engineering Works_Part 5: Framework on Specific Principles and Requirement for Civil Engineering Works; European Committee for Standardization (CEN): Brussels, Belgium, 2017.

3. ISO. ISO/TS 21929-2:2015—Sustainability in Building Construction-Sustainability Indicators—Part 2: Framework for the Development of Indicators for Civil Engineering Works; International Organization for Standardization (ISO): Geneva, Switzerland, 2015; Volume 1.

4. ISO. ISO 21931-2:2019-Sustainability in Buildings and Civil Engineering Works_Framework for Methods of Assessment of the Environmental, Social and Economic Performance of Construction Works as a Basis for Sustainability Assessment_Part 2: Civil Engineering; International Organization for Standardization (ISO): Geneva, Switzerland, 2019.

5. Mathern, A.; Ek, K.; Rempling, R. Sustainability-driven structural design using artificial intelligence. In Proceedings of the IABSE Congress New York City—The Evolving Metropolis, New York, NY, USA, 4-6 September 2019; pp. 1-8.

6. Du, G.; Safi, M.; Pettersson, L.; Karoumi, R. Life cycle assessment as a decision support tool for bridge procurement: Environmental impact comparison among five bridge designs. Int. J. Life Cycle Assess. 2014, 19, 1948-1964. [CrossRef]

7. Rempling, R.; Mathern, A.; Ramos, D.T.; Fernández, S.L. Automatic structural design by a set-based parametric design method. Autom. Constr. 2019, 108, 102936. [CrossRef]

8. Yepes, V.; Martí, J.V.; García-Segura, T. Cost and $\mathrm{CO}_{2}$ emission optimization of precast-prestressed concrete U-beam road bridges by a hybrid glowworm swarm algorithm. Autom. Constr. 2015, 49, 123-134. [CrossRef]

9. Penadés-Plà, V.; García-Segura, T.; Yepes, V. Accelerated optimization method for low-embodied energy concrete box-girder bridge design. Eng. Struct. 2019, 179, 556-565. [CrossRef]

10. Bragança, L.; Vieira, S.M.; Andrade, J.B. Early Stage Design Decisions: The Way to Achieve Sustainable Buildings at Lower Costs. Sci. World J. 2014, 2014, 1-8. [CrossRef] [PubMed]

11. Ek, K.; Mathern, A.; Rempling, R.; Karlsson, M.; Brinkhoff, P.; Norin, M.; Lindberg, J.; Rosén, L. A harmonized method for automatable life cycle sustainability performance assessment and comparison of civil engineering works design concepts. IOP Conf. Ser. Earth Environ. Sci. 2020, in press.

12. CEN. EN 15804:2012+A2:2019—Sustainability of Construction Works—Environmental Product Declarations-Core Rules for the Product Category of Construction Products; European Committee for Standardization (CEN): Brussels, Belgium, 2019.

13. EPD International AB. Product Category Rules (PCR)—Bridges, Elevated Highways and Tunnels. Available online: https://www.environdec.com/PCR/Detail/?Pcr=12257 (accessed on 12 December 2019).

14. ISO. ISO 15686-5:2017-Buildings and Constructed Assets—Service Life Planning_Part 5: Life-Cycle Costing; International Organization for Standardization (ISO): Geneva, Switzerland, 2017. 
15. ISO. ISO 14008:2019-Monetary Valuation of Environmental Impacts and Related Environmental Aspects; International Organization for Standardization (ISO): Geneva, Switzerland, 2019.

16. GaBi Professional, Version 9.5.2.49, Software-System and Data-Base for Life Cycle Engineering; Sphera: Leinfelden-Echterdingen, Germany, 2020.

17. Sala, S.; Crenna, E.; Secchi, M.; Pant, R. Global Normalisation Factors for the Environmental Footprint and Life Cycle Assessment. 2017. Available online: https://ec.europa.eu/jrc (accessed on 9 October 2020).

18. Sala, S.; Cerutti, A.K.; Pant, R. Development of a Weighting Approach for the Environmental Footprint. Luxembourg. 2018. Available online: https://ec.europa.eu/jrc (accessed on 9 October 2020).

19. European Commission. EF Reference Package 3.0. Available online: https://eplca.jrc.ec.europa.eu/LCDN/ developerEF.xhtml (accessed on 22 September 2020).

20. CEN. EN 16627:2015-Sustainability of Construction Works-Assessment of Economic Performance of Buildings-Calculation Methods; European Committee for Standardization (CEN): Brussels, Belgium, 2015.

21. Steen, B. The EPS 2015d Impact Assessment Method-An Overview; Swedish Life Cycle Center: Gothenburg, Sweden, 2015.

22. Hammervold, J.; Reenaas, M.; Brattebø, H. Environmental Life Cycle Assessment of Bridges. J. Bridg. Eng. 2013, 18, 153-161. [CrossRef]

23. Du, G.; Pettersson, L.; Karoumi, R. Soil-steel composite bridge: An alternative design solution for short spans considering LCA. J. Clean. Prod. 2018, 189, 647-661. [CrossRef]

24. Ahlroth, S.; Finnveden, G. Ecovalue08-A new valuation set for environmental systems analysis tools. J. Clean. Prod. 2011, 19, 1994-2003. [CrossRef]

25. Finnveden, G.; Håkansson, C.; Noring, M. A new set of valuation factors for LCA and LCC based on damage costs-Ecovalue 2012. In Proceedings of the 6th International Conference on Life Cycle Management in Gothenburg, Gothenburg, Sweden, 25-28 August 2013.

26. Laurent, A.; Olsen, S.I.; Hauschild, M.Z. Limitations of Carbon Footprint as Indicator of Environmental Sustainability. Environ. Sci. Technol. 2012, 46, 4100-4108. [CrossRef] [PubMed]

27. Yepes, V.; García-Segura, T.; Moreno-Jiménez, J. A cognitive approach for the multi-objective optimization of RC structural problems. Arch. Civ. Mech. Eng. 2015, 15, 1024-1036. [CrossRef]

28. Giunta, M. Assessment of the environmental impact of road construction: Modelling and prediction of fine particulate matter emissions. Build. Environ. 2020, 176, 106865. [CrossRef]

29. Cheriyan, D.; Choi, J.-H. A review of research on particulate matter pollution in the construction industry. J. Clean. Prod. 2020, 254, 120077. [CrossRef]

30. Ek, K.; Mathern, A.; Rempling, R.; Rosén, L.; Claeson-Jonsson, C.; Brinkhoff, P.; Norin, M. Multi-criteria decision analysis methods to support sustainable infrastructure construction. In Proceedings of the IABSE Symposium 2019: Towards a Resilient Built Environment-Risk and Asset Management, Guimarães, Portugal, 27-29 March 2019; p. 8.

31. Belton, V.; Stewart, T.J. Multiple Criteria Decision Analysis-An Integrated Approach; Kluwer Academic Publishers: Dordrecht, The Netherlands, 2002.

32. Penadés-Plà, V.; García-Segura, T.; Martí, J.V.; Yepes, V. A Review of Multi-Criteria Decision-Making Methods Applied to the Sustainable Bridge Design. Sustainability 2016, 8, 1295. [CrossRef]

33. Eurobitume. The Eurobitume Life-Cycle Inventory for Bitumen, Version 3.0; European Bitumen Association: Brussels, Belgium, December 2019.

34. Legret, M.; Pagotto, C. Evaluation of pollutant loadings in the runoff waters from a major rural highway. Sci. Total Environ. 1999, 235, 143-150. [CrossRef] [PubMed]

35. Birgisdottir, H.; Gamst, J.; Christensen, T.H. Leaching of PAHs from Hot Mix Asphalt Pavements. Environ. Eng. Sci. 2007, 24, 1409-1422. [CrossRef]

36. Ihs, A.; Möller, S. VTI Notat 53-2004 -Beräkningsmodell för Vinterväghållningskostnader; VTI: Linköping, Sweden, 2004.

37. Swedish National Road and Transport Research Institute (VTI). VTI Slitagemodell. Available online: http://www.metodgruppen.nu/web/page.aspx?refid=127 (accessed on 8 October 2020).

38. Magnusson, K.; Eliasson, K.; Fråne, A.; Haikonen, K.; Hultén, J.; Olshammar, M.; Stadmark, J.; Voisin, A. Swedish Sources and Pathways for Microplastics to the Marine Environment; Swedish Environmental Protection Agency: Stockholm, Sweden, 2016; Volume C 183. 
39. Erlandsson, M. Miljödata för arbetsfordon; Svenska Miljöinstitutet: Stockholm, Sweden, 2013; Volume BPI 13/1.

40. CEN. EN 16757:2017-Sustainability of Construction Works-Environmental Product Declarations—Product Category Rules for Concrete and Concrete Elements; European Committee for Standardization (CEN): Brussels, Belgium, 2017.

41. Aquajet Systems AB. Product sheet, Aqua Cutter 710H. Aquajet Systems AB. Available online: https: //www.aquajet.se/wp-content/uploads/2014/06/leaflet_aqua-cutter-710H.pdf (accessed on 8 October 2020).

42. Lindstrom, D.; Wallinder, I.O. Long-term use of galvanized steel in external applications. Aspects of patina formation, zinc runoff, barrier properties of surface treatments, and coatings and environmental fate. Environ. Monit. Assess. 2010, 173, 139-153. [CrossRef] [PubMed]

43. AGA. Product Catalog. Gassvetsning, skärning, lödning och värmning. Available online: https://www.linde-gas.se/sv/images/Cutting_Welding_Catalogue_2018_SE_web_tcm586-137940.pdf (accessed on 8 October 2020).

Publisher's Note: MDPI stays neutral with regard to jurisdictional claims in published maps and institutional affiliations.

(C) 2020 by the authors. Licensee MDPI, Basel, Switzerland. This article is an open access article distributed under the terms and conditions of the Creative Commons Attribution (CC BY) license (http://creativecommons.org/licenses/by/4.0/). 